\title{
Late Ordovician-Early Silurian (Ashgillian-Llandovery) sea level curve derived from conodont community analysis, Anticosti Island, Québec
}

\author{
Shunxin Zhang, Christopher R. Barnes* \\ School of Earth and Ocean Sciences, University of Victoria, P.O. Box 3055, Victoria, BC, Canada V8W 3 P6
}

Received 15 January 2001; accepted 11 October 2001

\begin{abstract}
Earlier workers have established sea level curves for the Ashgillian-Llandovery sequence on Anticosti Island, Québec, Canada, based on sedimentology and on brachiopod and reef communities. The complete Anticosti sequence has been collected for conodonts to provide a database of over 77600 conodonts derived from 272 samples through the $800-1100 \mathrm{~m}$ sequence. This paper uses a statistical analysis of the database to establish the pattern of conodont communities and their interpreted water depths. This allows the establishment of a eustatic sea level curve for the sequence. This curve is in general agreement with those of the earlier workers, but is more detailed and better constrained stratigraphically given the large sampling program. The curve reflects more oscillating sea level changes for the whole sequence than those constructed earlier, and different water depths for certain intervals from those established earlier. The curve is valuable given that the Anticosti sequence is one of the most complete in the world for this interval, and its divergence from global eustatic curves for this interval is noted. (C) 2002 Published by Elsevier Science B.V.
\end{abstract}

Keywords: Ashgillian; Llandovery; eustasy; cluster analysis; conodonts

\section{Introduction}

Anticosti Island, located in the Gulf of St. Lawrence, eastern Canada, is underlain by Upper Ordovician (Ashgillian) and Lower Silurian (Llandovery) strata referred to the Vauréal, Ellis Bay, Becscie, Merrimack, Gun River, Jupiter and Chicotte formations (Fig. 1). The entire sequence is

\footnotetext{
* Corresponding author. Tel.: +1-250-721-8847; Fax: +1-250-721-6200.

E-mail addresses: zhangs@uvic.ca (S. Zhang), crbarnes@uvic.ca (C.R. Barnes).
}

represented by richly fossiliferous limestones, minor shales and siliciclastic sediments, totaling $800-1100 \mathrm{~m}$ in thickness with virtually no stratigraphic breaks. During the latest Ordovician and early Silurian, the Anticosti Basin was situated at paleolatitudes of $15-20^{\circ}$ south of equator, and on the northwest margin of the Iapetus Ocean. Most of the Upper Ordovician and Lower Silurian sediments were deposited in a shallow, storm-influenced, open-marine sublittoral environment. The Anticosti Basin was subsiding slowly during this period to maintain a complete record of sedimentation and was relatively unaffected by post-Ta- 


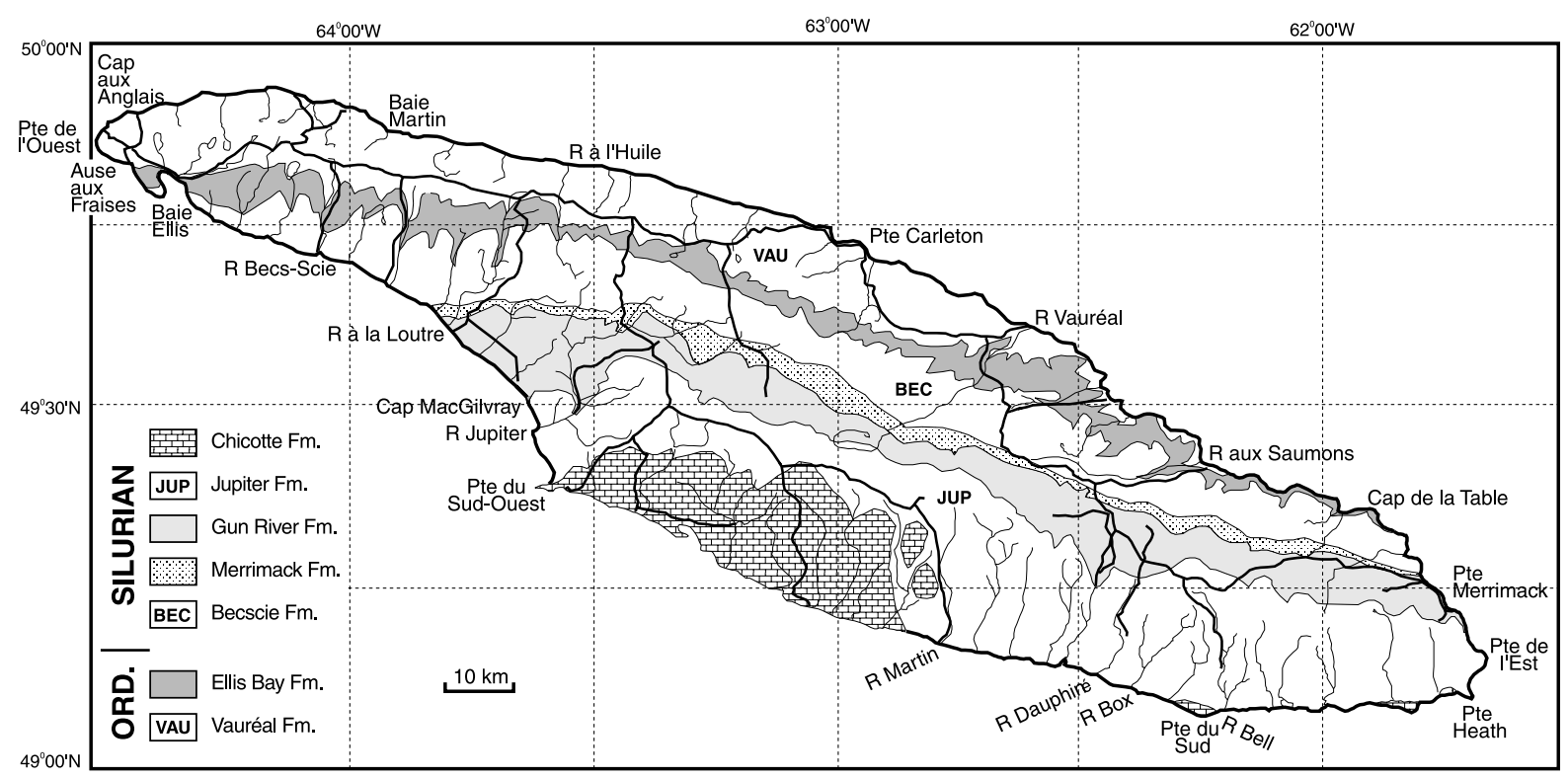

Fig. 1. Geological map of Anticosti Island showing formation outcrop pattern (from Jin and Copper, 1999).

conic orogenic clastic influx that affected the New York-Ontario region to the southwest. The stratigraphic sequence within the basin (Fig. 2), therefore, provides a sensitive indicator of subtle eustatic change through this time interval.

In this paper, we use the Ashgillian as a series and the Hirnantian/Gamachian as stages of the uppermost Ordovician. We recognize that the IUGS Subcommission on Ordovician Stratigraphy is redefining and naming Ordovician chronostratigraphic units and that the redefined and possibly renamed Ashgillian will become the highest stage within a new Upper Ordovician series (Barnes, 1992) but these decisions have yet to be finalized.

The sea level fluctuations in the Anticosti Basin during Ashgillian and Llandovery time have been reconstructed by Johnson et al. (1981), Copper and Long (1998), Jin and Copper (1999) and Dewing (1999). Two different approaches have been used to identify sea level change. One is based on benthic fossil assemblages, mainly brachiopods, to interpret changes in water depth (Johnson et al., 1981; Jin and Copper, 1999; Dewing, 1999). The other is based mainly on the study of sequence stratigraphy, depositional environments and reef development (Sami and Des- rochers, 1992; Copper and Long, 1989, 1990, 1998; Fig. 2).

This present study documents changes in the conodont faunas and communities and interprets this response in terms of sea level change. Conodont samples have been collected at closely spaced intervals through the entire sequence and the taxonomic descriptions have been completed. The temporal distribution of faunas has allowed a refined biostratigraphy. The spatial and temporal distributions in terms of community partitioning and evolution has been established (Zhang and Barnes, 2002b). We now utilize these latter data, along with the previous studies on stratigraphy, sedimentology, and benthic faunas, to generate a more refined eustatic sea level curve for this time interval.

The stratigraphic subdivisions for Vauréal, Ellis Bay, Becscie, Merrimack, Gun River, Jupiter and Chicotte formations in this study are mainly based on Bolton (1972), Petryk (1981a) and Uyeno and Barnes (1983). More recent subdivisions for the uppermost Vauréal and Ellis Bay formations (Long and Copper, 1987), Becscie and Merrimack formations (Copper and Long, 1989), and Jupiter Formation (Copper and Long, 1990) have been formally published (Fig. 2) based largely on 
sections from the eastern part of the island. The conodont databases for the Vauréal, Ellis Bay, Jupiter and Chicotte formations adopted by this study were established by Nowlan and Barnes (1981), McCracken and Barnes (1981), Barnes (1988) and Uyeno and Barnes (1983) on the earlier subdivisions.

\section{Methodology}

\subsection{Database}

The database for this study consists of 272 con- odont samples (av. $3 \mathrm{~kg}$ ) from different sources: (1) 102 samples from the Ordovician Vauréal Formation which yielded nearly 50000 disjunct conodont elements representing 35 multielement species (Nowlan and Barnes, 1981); (2) 47 selected samples from the Ellis Bay Formation at Baie Ellis that produced 3600 conodont elements representing 21 multielement species, 15 of them extending from the Vauréal Formation (McCracken and Barnes, 1981); (3) 63 selected samples from the Becscie, Merrimack and Gun River formations which contain over 19000 conodont elements (Zhang and Barnes, 2002a) representing 24 multielement species, several of which are

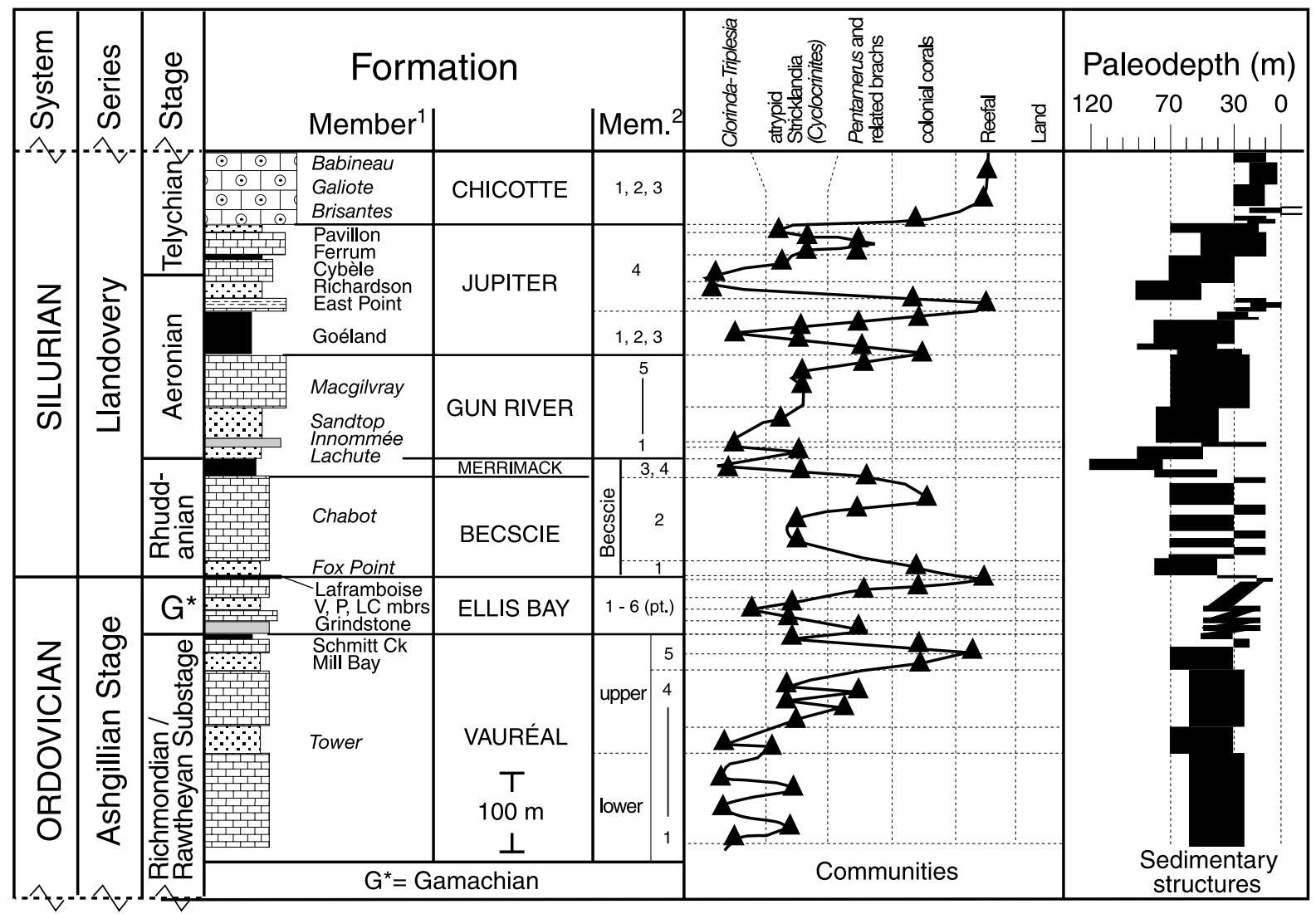

Fig. 2. Stratigraphic framework of the Anticosti succession, showing the main reef levels and brachiopod communities, and approximate sea level curve based on fossil data and sedimentology (modified from Copper and Long, 1998). Under Member ${ }^{1}$, the formal member names are shown in regular font, which is based on Long and Copper (1987) and Copper and Long (1989, 1990) (LC=Lousy Cove M.; $\mathrm{P}=$ Prinsta M.; V=Velleda M.); the informal member names are shown in italic font, which are from Copper and Long (1998); under Member ${ }^{2}$, the upper and lower members of the Vauréal Fm. are from Bolton (1972) and Nowlan and Barnes (1981), members 1-6 of Ellis Bay Fm. are from Bolton (1972) (member 6 includes only the lower 2m of the member as originally defined), members 1-4 of Jupiter Fm. are from Bolton (1972) and Uyeno and Barnes (1983) with others from Petryk (1981a). 
new; (4) 60 samples from the Jupiter and Chicotte formations that contain over 5000 conodont elements representing 33 multielement species (Uyeno and Barnes, 1983), most of which are different from those in the underlying Becscie, Merrimack and Gun River formations. In summary, the total database includes 272 samples that yielded over 77600 conodont elements referred to 83 different species.

\subsection{Data processing and program employed in the conodont community analysis}

In analyzing the data to establish conodont communities, we have employed cluster analysis of the species abundance data (number of conodont elements for each species per kilogram) using SPSS version 6.1 for the Macintosh (SPSS, 1994). Both Q- and R-mode hierarchical cluster analyses were performed for both cases (samples) and variables (species). The recorded species abundance for each sample was divided into seven intervals $(<1,1-4,5-9,10-24,25-49,50-99$, and $\geq 100)$. Pearson's correlation coefficient was used as an index of similarity and clusters were formed using the within-groups linkage method. The intervals of taxonomic counted abundance are expressed as a graded series of dots that are plotted at the intersection of certain species and samples. The community partitioning pattern is determined from the assemblages of dots representing distinctive groupings of samples and species. This methodology was adopted by Zhang and Barnes (2002b) and earlier by Westrop and Cuggy (1999) in a study of Late Cambrian trilobites.

Three analyses were designed and performed for the Vauréal Formation (Figs. 3 and 4), the Ellis Bay Formation (Figs. 5 and 6), and the combined Becscie, Merrimack, Gun River, Jupiter and Chicotte formations (Figs. 7-11). Cluster analysis tends to divide an ecological gradient into discrete units, whereas the gradational nature of the conodont community groups is evident in the abundance data shown in the Q- and R-mode dendrograms.

\subsection{Conodont community partitioning among Late Ordovician and Early Silurian conodonts}

Several studies have discussed the ecological partitioning of conodonts in the Late Ordovician and Early Silurian. The pattern of conodont communities through this interval is also influenced strongly by the mass extinction, produced by the terminal Ordovician glaciation in North Africa that resulted in few species surviving through this event (Barnes and Bergström, 1988). Ordovician faunas are influenced severely by faunal provincialism; but certain provinces exhibit a separate conodont community pattern that generally shows an onshore to offshore community partitioning (e.g. Barnes and Fåhræus, 1975; Sweet and Bergström, 1974, 1984; Bergström, 1990; Pohler and Barnes, 1990). Faunal provincialism is far less pronounced in the Silurian, but the onshore-offshore pattern of conodont communities is still evident (e.g. Aldridge, 1976; Le Fèvre et al., 1976; Aldridge and Mabillard, 1981; McCracken and Barnes, 1981; Barrick, 1983; Idris, 1984; Aldridge and Jeppsson, 1984; Zhang and Barnes, 2002b). Although simple models involving partitioning as a function of distance from shore or water depth do not explain all the distribution patterns shown by Ordovician and Silurian conodonts, a few species - called ecological specialists by Aldridge and Jeppsson (1984) - appear to have been restricted to, or especially abundant in, particular nearshore or offshore environments. For example, Aldridge and Jeppsson (1984) argued that Llandovery species of Icriodella and Distomodus were specialists in nearshore environments, whereas those of Decoriconus and Dapsilodus as well as Oulodus? fluegeli were specialists in offshore environments. From these more general studies, it has been possible to use more detailed sampling strategies to examine statistically the distribution pattern of conodonts (see papers in Barnes, 1976; Clark, 1984), and more specifically for the Early Silurian of Anticosti Island (Zhang and Barnes, 2002b). 
2.4. Shelly fossil communities, lithofacies and sea level curves

Detailed studies of Late Ordovician and Early Silurian stratigraphy, sedimentology, and macrofaunas on Anticosti Island have been undertaken by Bolton (1972; includes a summary of earlier work), Barnes et al. (1981), Petryk (1981a), Lespérence (1981), Barnes (1989), Sami and Desrochers (1992), Copper and Long (1998), Jin and Copper (1999) and Dewing (1999). From the combination of stratigraphy, sedimentology, and faunal communities, various attempts have been made to establish a sea level curve for all or parts of this interval. A definite advantage is that this sequence is one of the most complete in the world and does not exhibit major tectonic or depositional change through this period. Being dominantly composed of limestones that can reveal subtle eustatic variations, the sequence is ideal to record those associated with the development, peak, and waning phases of the terminal Ordovician glaciation. Although prevailing thought is that the glaciation was restricted to the Hirnantian (late Ashgillian) (e.g. Brenchley et al., 1994), there is some evidence to suggest that ice accumulated through the Ashgillian (Barnes, 1986) to peak in the Hirnantian, and recent isotope and stratigraphic data suggest that three smaller glacial phases occurred within the Llandovery or into the early Wenlock (Grahn and Caputo, 1992; Azmy et al., 1998). The nature of eustatic change during the Late Ordovician-Early Silurian is of particular interest given the relationship to coupled ocean-atmosphere changes associated with the glaciation and given the apparent paradox of continental glaciation developing during a time when $\mathrm{CO}_{2}$ levels were considered to be 14-18 times present atmospheric levels (Berner, 1994; Poussart et al., 1999).

Establishing sea level curves is fraught with difficulties, especially if the local area being considered has an active tectonic history. Assembly of regional curves to establish a global sea level curve has been attempted by several workers (e.g. Fortey, 1984; Ross and Ross, 1992 for the Ordovician; Ross and Ross, 1996; Loydell, 1998 for the Silurian; see also papers in Landing and
Johnson, 1998). The validity of these curves depends on the quality of both the regional data and the interpretations. The purpose of the present paper is to document the regional sea level curve for the Anticosti Basin based on new detailed conodont data, especially the pattern of conodont communities, for a region that could serve as a standard reference for the Llandovery (Barnes, 1989).

To refine the regional sea level curve for the Anticosti Basin, most of the characteristic species of the conodont communities recognized in this study have been used to establish the relative water depths. The latter have been estimated through the detailed studies of Llandovery sediments and brachiopods of Anticosti Island by Sami and Desrochers (1992), Copper and Long (1998), Jin and Copper (1999) and Dewing (1999). Their interpretations have been adopted as a reference to determine the interpreted water depths that each conodont community could represent.

\section{Sea level changes during the Richmondian - analysis I for the Vauréal Formation}

The Vauréal Formation consists of about $1100 \mathrm{~m}$ of thinly bedded lime mudstone, limestone, shale and minor sandstone, thickening by about $60 \mathrm{~m}$ beneath the south coast, as determined from drill-hole data (Roliff, 1968). The total thickness of the exposed upper Vauréal Formation is about $330-400 \mathrm{~m}$ and the conodont fauna was assigned to Fauna 12 of Richmondian age (Nowlan and Barnes, 1981).

The exposed Vaureal Formation is divided into lower and upper members by Bolton (1972), which was adopted by Nowlan and Barnes (1981). The lower member consists of gray shale with interbedded blue-gray to reddish gray or brown, fine-grained to dense limestone with intraformational conglomerate; the limestone beds increase in thickness upward and become nodular. The upper member is composed of gray, finegrained to dense limestone with abundant intraformational conglomerate, gray shale partings and lenses, fine cross-bedding and channel-fill 
structures. Small reefs occur in the upper part of the formation (Copper and Long, 1998). The sections at Rivière à l'Huile, and Cap aux Anglais and Pointe de l'Ouest measured by Nowlan and Barnes (1981) (Figs. 1 and 4) are equivalent to the lower and upper members, respectively. The lower member probably represents relatively unstable, deep subtidal conditions, whereas the upper member reflects a shallower subtidal environment (Nowlan and Barnes, 1981).

Earlier results of cluster analysis for the conodonts from the Vauréal Formation (Nowlan and Barnes, 1981) showed three clustered groups interpreted as representing three conodont ecozones - Amorphognathus-Plectodina predominating in the lower part of the formation, Phragmodus in the middle, and Oulodus-Aphelognathus in the upper part.

Analysis I (Figs. 3 and 4) employed the same database as used by Nowlan and Barnes (1981), which includes 102 samples producing 49473 conodont elements from sections at Rivière à l'Huile, Cap aux Anglais, Point à la Goélette, Pointe de l'Ouest, and Anse aux Fraises at the western end of Anticosti Island (Figs. 1 and 4). These conodont elements were recognized as 35 species, most of which were identified as multielement apparatuses by Nowlan and Barnes (1981), and a few form species. Some of their multielement species, such as those of Panderodus, could perhaps be synonymized. However, in order to compare the results with those of Nowlan and Barnes (1981) all of these authors' species names are retained in this analysis. Most of the conodont species from the Vauréal stratigraphically range through much of the formation and do not allow a precise biozonation. However, a repetitive ecological distribution of faunal associations of many species was recognized by both Nowlan and Barnes (1981) and this study.

Cluster analysis in this study defined three clustered groups (Fig. 3, boxed in by dashed line and named in hollow letters), similar in composition to those of Nowlan and Barnes (1981). They are Aphelognathus n. sp. A (Aph.), Amorphognathus ordovicicus-Panderodus cf. P. serratus (Am.Pan.) and Phragmodus undatus (Ph) associations. There was not a close relationship between Amorphognathus ordovicicus and Plectodina as suggested by Nowlan and Barnes (1981). The analysis also shows a similar stratigraphic distribution of different associations, whereby Amorphognathus ordovicicus-Panderodus cf. $P$. serratus (Am.Pan.), Phragmodus undatus $(P h)$ and Aphelognathus n. sp. A (Aph.) dominated in the lower, middle and upper parts of the formation, respectively. The principal difference between the two analyses is that most of the samples from the upper part of the Cap aux Anglais section were grouped into the Oulodus-Aphelognathus ecozone (Nowlan and Barnes, 1981), but are grouped into the Phragmodus undatus association herein (Fig. 3, boxed in by dashed line and named in hollow letters).

One of the three ecozones recognized by Nowlan and Barnes (1981), Oulodus-Aphelognathus, was interpreted as representing a shallow subtidal environment. This is the same as the Aphelognathus $\mathrm{n}$. sp. A (Aph.) association recognized in this study. The genus Oulodus appears not to have the same environmental preference as Aphelognathus, being present in almost all samples. However, the Q- and R-mode cluster analysis shows that the two Vauréal species of Oulodus, O. rohneri and O. ulrichi, always exhibit an antipathetic relationship to each other in terms of relative abundance

\footnotetext{
Fig. 3. Results of Q- and R-mode cluster analysis of 102 samples from Vauréal Formation (sample data from Nowlan and Barnes, 1981). Samples are in Q-mode clustering, taxa are in R-mode clustering order, and relative abundance of taxa are expressed as a graded series of dots. Intersections of Q- and R-clusters defined three conodont communities (boxed in by dashed line and named with hollow letters), indicated by the abbreviations: Aph., Aphelognathus n. sp. A; Am.-Pan., Amorphognathus ordovicicus-Panderodus cf. P. serratus; Ph., Phragmodus undatus. Intersections of Q- and R-clusters defined six conodont communities by employing the species of Oulodus (shaded and named in bold italic; discussed in the text), indicated by the abbreviations: Aph.-O.r., Aphelognathus n. sp. A-Oulodus rohneri; Am.-Pan.-O.u., Amorphognathus ordovicicus-Panderodus cf. P. serratus-O. ulrichi; Am.-Pan.-O.r., Amorphognathus ordovicicus-Panderodus cf. P. serratus-Oulodus rohneri; Ph.-O.r., Phragmodus undatus-Oulodus rohneri; Ph.-O.u., Phragmodus undatus-Oulodus ulrichi; Ph.-O.r.-Aph., Phragmodus undatus-Oulodus rohneri-Aphelognathus.
} 


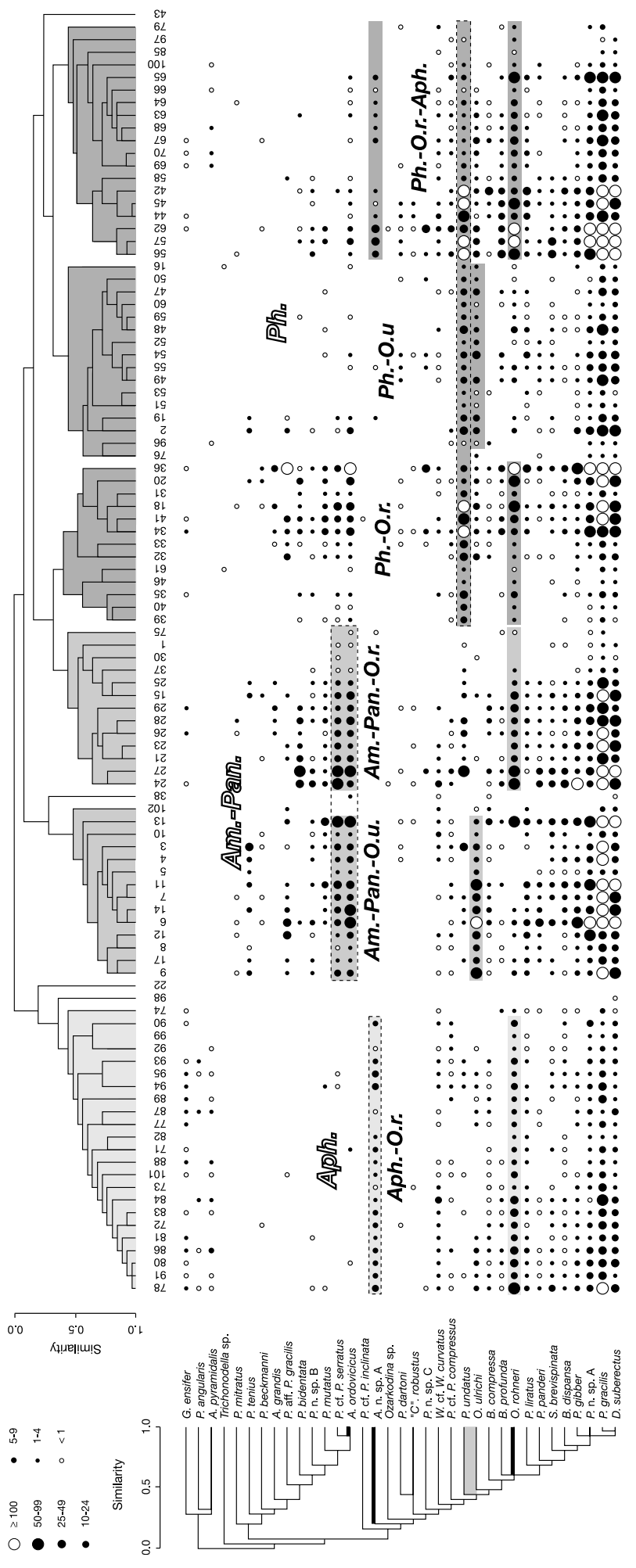


per sample. The species of Oulodus can be used to subdivide the community groups.

Fig. 3 also shows a more detailed partition of communities by employing species of Oulodus (boxed in with shading and named in bold italics). The Aphelognathus n. sp. A-Oulodus rohneri (Aph.-O.r.) community, as with Aphelognathus n. sp. A $(A p h$. $)$ in the upper part of the formation, cannot be subdivided further. The Amorphognathus ordovicicus-Panderodus cf. P. serratus (Am.$P a n$.) community in the lower part of the formation can be divided into the $A$. ordovicicus $-P$. cf. P. serratus-Oulodus rohneri (Am.-Pan.-O.r.) and the $A$. ordovicicus $-P$. cf. $P$. serratus-Oulodus ulrichi (Am.-Pan.-O.u.) community. The Phragmodus undatus community in the middle part of the formation can be divided into the Phragmodus undatus-Oulodus rohneri (Ph.-O.r.), the P. undatus $-O$. ulrichi (Ph.-O.u.) and the P. undatus-O. rohneriAphelognathus n. sp. A (Ph.-O.r.-Aph.) communities. Both the first and last of these groups, Ph.O.r. and Ph.-O.r.-Aph., contain O. rohneri, but it is easy to differentiate them on the basis of Aphelognathus $\mathrm{n}$. sp. A that appears in 12 of the 19 samples of the group Ph.-O.r.-Aph.

Based on the depositional interpretations of Bolton (1972), Nowlan and Barnes (1981), Petryk (1981a) and Copper and Long (1998), Amorphognathus from the lower part of the formation and Aphelognathus from the upper part of the formation preferred relatively deeper and shallower water, respectively. Elsewhere, Leatham (1997) also found that Aphelognathus-dominated faunas characterize more nearshore environments. Nowlan and Barnes (1981) revealed that Phragmodus appears in high abundance in deeper water settings. Seddon and Sweet (1971) and Barnes and Fåhræus (1975) also suggested that Phragmodus was usually a relatively deep water, subtidal inhabitant. Thus, Phragmodus, Amorphognathus and Aphelognathus represent three different subtidal water depths from deeper to shallower.

The question remains whether the associations dominated by the above-mentioned three genera could represent the same water depth, but differentiated by some other environmental factors. A possible answer comes by considering the distributional pattern of Oulodus species. As indicated above, Aphelognathus had the shallowest environment preference among Phragmodus, Amorphognathus and Aphelognathus, and can be used as an indicator to distinguish the water depth difference between Oulodus ulrichi and $O$. rohneri. Twenty-three samples are grouped in the Aphelognathus n. sp. A-O. rohneri community, each contains 1-99 specimens of O. rohneri, but only 11 samples yield $<1-4$ specimens (per $\mathrm{kg}$ ) of $O . u l$ richi. Thus, O. rohneri had a stronger shallow water preference than $O$. ulrichi. From this, it is inferred that the communities of Amorphognathus ordovicicus-Panderodus cf. P. serratus (Am.-Pan.) and Phragmodus undatus $(P h$.), which both contain more $O$. ulrichi, indicate deeper water than those yielding more $O$. rohneri. The $P$. undatus $-O$. rohneri-Aphelognathus n. sp. A (Ph.-O.r.-Aph.) community is the shallowest of the three communities within the Phragmodus undatus community because of the presence of Aphelognathus n. sp. A.

Among all six conodont communities, Aphelognathus n. sp. A-Oulodus rohneri (Aph.-O.r.) and Phragmodus undatus-Oulodus ulrichi (Ph.-O.u.) represent the shallowest and deepest Vauréal environments, respectively (Figs. 4 and 12). Species abundance and diversity are both lower in these two extreme communities than in the others. For example, the species number in community Aph.O.r. ranges from 7 to 21 (per $\mathrm{kg}$ ) which is comparable to that of community Ph.-O.u. which ranges from 5 to 16 . The specimen number of the characteristic species in these two communities is below 50 in almost all samples. All other intermediate communities have higher species abundance and diversity (Fig. 3). Copper and Long's (1998) sea level curve, established using macrofossils and sediments, indicates that the paleobathymetry for the Vauréal Formation ranged from 20 to $70 \mathrm{~m}$. Based on this, it can be inferred

Fig. 4. Inferred paleodepth and sea level changes based on the distribution of the six conodont communities identified by cluster analysis through a composite section from five different sections of Vauréal Formation. 
Paleodepth (m)

Sea-level curve

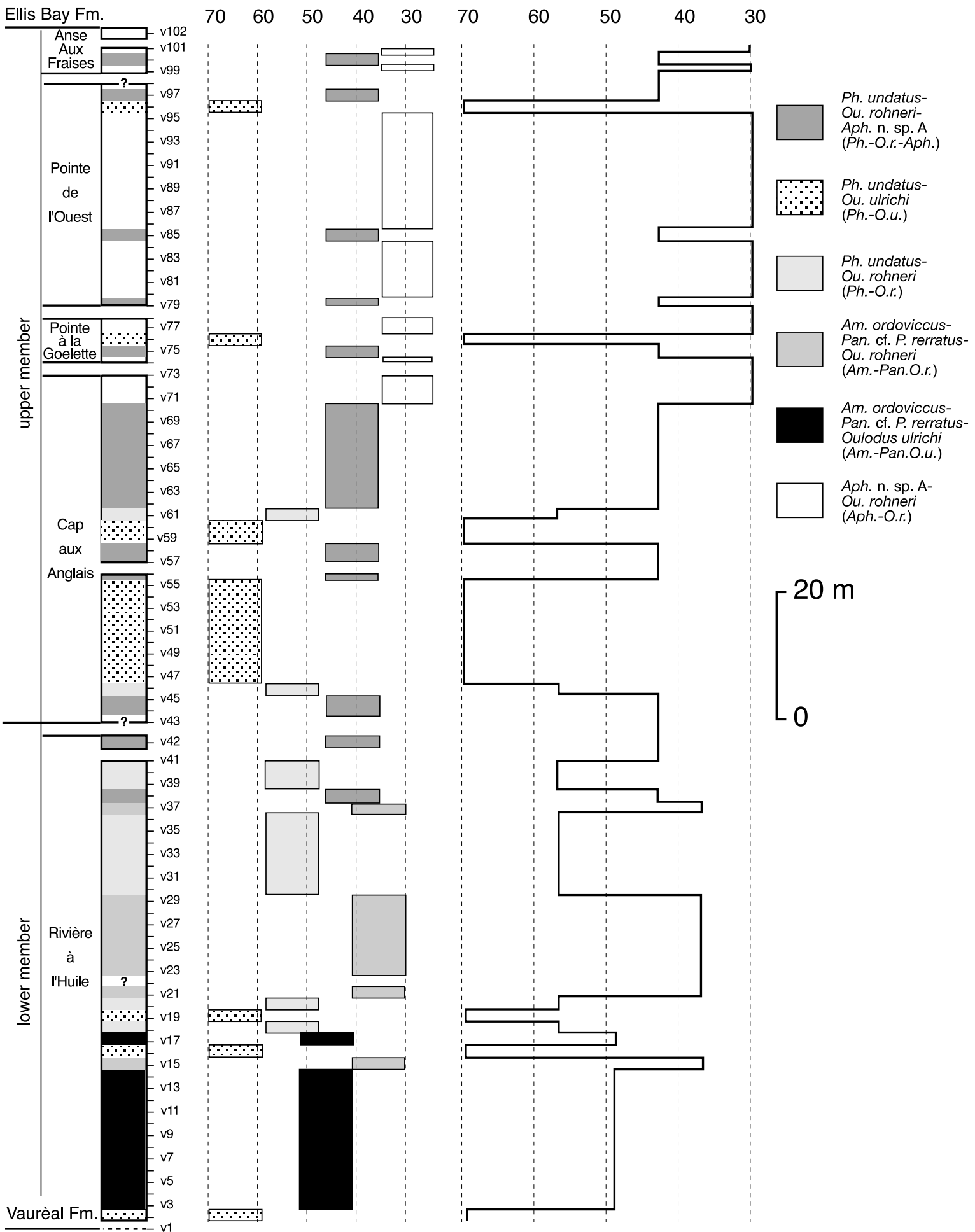


that the habitat of Aphelognathus n. sp. A-Oulodus rohneri (Aph.-O.r.) and Phragmodus undatusOulodus ulrichi (Ph.-O.u.) was about 20 and $70 \mathrm{~m}$ below the sea level, respectively. All other communities were between these two depths (Figs. 4 and 12).

Within upper member of the Vauréal Formation, a new genus Gamachignathus appeared, that was represented by two species, $G$. ensifer McCracken, Nowlan and Barnes and G. hastatus McCracken, Nowlan and Barnes (McCracken et al., 1980). This genus became a dominant faunal component of the overlying Ellis Bay Formation (McCracken and Barnes, 1981). In the Vauréal Formation samples, the number of specimens of one species, G. ensifer, is low, being equal to or lower than 4. Of the 29 samples that include the genus, 17 occur in the Aphelognathus n. sp. AOulodus rohneri (Aph.-O.r.) community (Fig. 3). It is absent in the $A$. ordovicicus $-P$. cf. P. serratus-Oulodus rohneri (Am.-Pan.-O.r.) and Phragmodus undatus-Oulodus ulrichi (Ph.-O.u.) communities. Therefore, it is concluded that $G$. ensifer preferred shallow water.

The general distribution of conodont communities through the five sections of the Vauréal Formation (Fig. 4) indicates that the Rivière à l'Huile section was deposited in intermediate depths, the lower part of the Cap aux Anglais section in the deepest depths, and the upper part of the Cap aux Anglais section and Pointe de l'Ouest sections in the shallower depths. This reflects a sea level history of deepening in the early Vauréal and shallowing in late Vauréal times. Fig. 4 shows the detailed distribution of conodont communities on sample-by-sample basis, and the derived sea level curve, which reveals that each major deepening or shallowing phase included several minor phases of shallowing or deepening.

\section{Sea level changes during the Gamachian - analysis II for the Ellis Bay Formation}

The Ellis Bay Formation conformably overlies the Vauréal Formation. Its conodont fauna was designated as Fauna 13 and proposed as being representative of the type Gamachian Stage of the Cincinnatian Series, latest Ordovician (and equivalent to the Hirnantian of the Ashgillian Series) (McCracken and Barnes, 1981). The Ellis Bay Formation is the thickest and most complete section of Hirnantian-equivalent age in the world. It represents the main phase of terminal Ordovician glaciation, and the alternating members are considered to reflect at least three cycles of glacial-interglacial cycles (McCracken and Barnes, 1981; Petryk, 1981b; Barnes, 1988). The thickness of the Ellis Bay Formation varies between $53 \mathrm{~m}$ and $96 \mathrm{~m}$ (Bolton, 1972), and the formation was divided into six members by Bolton (1972) based on argillaceous content. Members 1, 3 and 5 consist of shale with interbeds of argillaceous limestone, whereas members 2,4 and 6 consist predominantly of limestone with shale interbeds or partings. Petryk (1981a) made adjustments to the member divisions, introducing two thin members from the lower part of Bolton's member 6 and incorporating most of that member into the overlying Becscie Formation. The depositional environments are represented by three main lithofacies: (a) nearshore, arenaceous and calcareous deposits at Rivière aux Saumons; (b) intermediate, argillaceous and calcareous deposits at $\mathrm{Ri}$ vière Vauréal; and (c) offshore, alternating argillaceous and calcareous deposits at Baie Ellis (McCracken and Barnes, 1981). The present study deals only with offshore lithofacies, its conodont fauna being dominated by Gamachignathus ensifer and G. hastatus.

Analysis II employed part of the database as used by McCracken and Barnes (1981) to include 47 samples producing 3600 conodont elements from the lower to middle part of the Ellis Bay Formation at the Baie Ellis section (i.e. the Ellis Bay Formation as defined more restrictively by Petryk (1981a)). These conodont elements were assigned to 21 species, most of which were identified as multielement apparatuses by McCracken and Barnes (1981), and few form species. As discussed in analysis I, although a few multielement apparatuses are in need of revision, all species names are retained for use in this analysis.

The cluster analysis performed by McCracken and Barnes (1981) involved all samples from the three different lithofacies (a-c above), and they 
recognized communities $\mathrm{A}, \mathrm{B}, \mathrm{C}, \mathrm{D}$, and $\mathrm{E}$. These reflect the distribution of conodont communities from east to west across the island. Most samples from the Baie Ellis section are grouped in community A, which generally represents an offshore environment.

In comparison with the Vauréal Formation, the Ellis Bay Formation has a less abundant and diverse conodont fauna. Of the 21 species present, the most productive samples only produce 14 species. The cluster analysis in this study identifies four communities (Fig. 5), namely the Gamachignathus ensifer (G.e.), Phragmodus undatus (Ph.), G. ensifer-G. hastatus-Panderodus panderi (G.e.-G.h.-P.p.), and G. ensifer-G. hastatus (G.e.-G.h.) communities.

As indicated earlier, members 1,3 and 5 consist of shale with interbeds of argillaceous limestone and represent deeper, presumed interglacial phases, whereas members 2,4 and 6 consist predominantly of limestone with shale interbeds or partings and represent the shallower, presumed glacial phases. The lithofacies suggest three cycles of deepening-shallowing. To interpret the relative water depth of each community represented, there are some noteworthy trends in the pattern of communities and lithofacies.

Of the four communities recognized herein, when the distribution of two of them, Gamachignathus ensifer (G.e.) and G. ensifer-G. hastatus-Panderodus panderi (G.e-G.h.-P.p.), is plotted against the different lithofacies of members 1 and 2 (Fig. 6), the former is the major component in member 1 , and the latter in member 2. Hence, firstly it is inferred that the Gamachignathus ensifer (G.e.) community represents a deeper water habitat than the G. ensifer-G. hastatus-Panderodus panderi (G.e.-G.h.-P.p.) community.

Secondly, based on analysis I for the Vauréal Formation, the Phragmodus undatus $(\mathrm{Ph})$ community is interpreted as having the deepest water preference among the four communities in analysis II.

Thirdly, the differences between communities Gamachignathus ensifer-G. hastatus-Panderodus panderi (G.e.-G.h.-P.p.) and G. ensifer-G. hastatus (G.e.-G.h.) are: (a) the former contains $P$. panderi whose elements are robust and have a
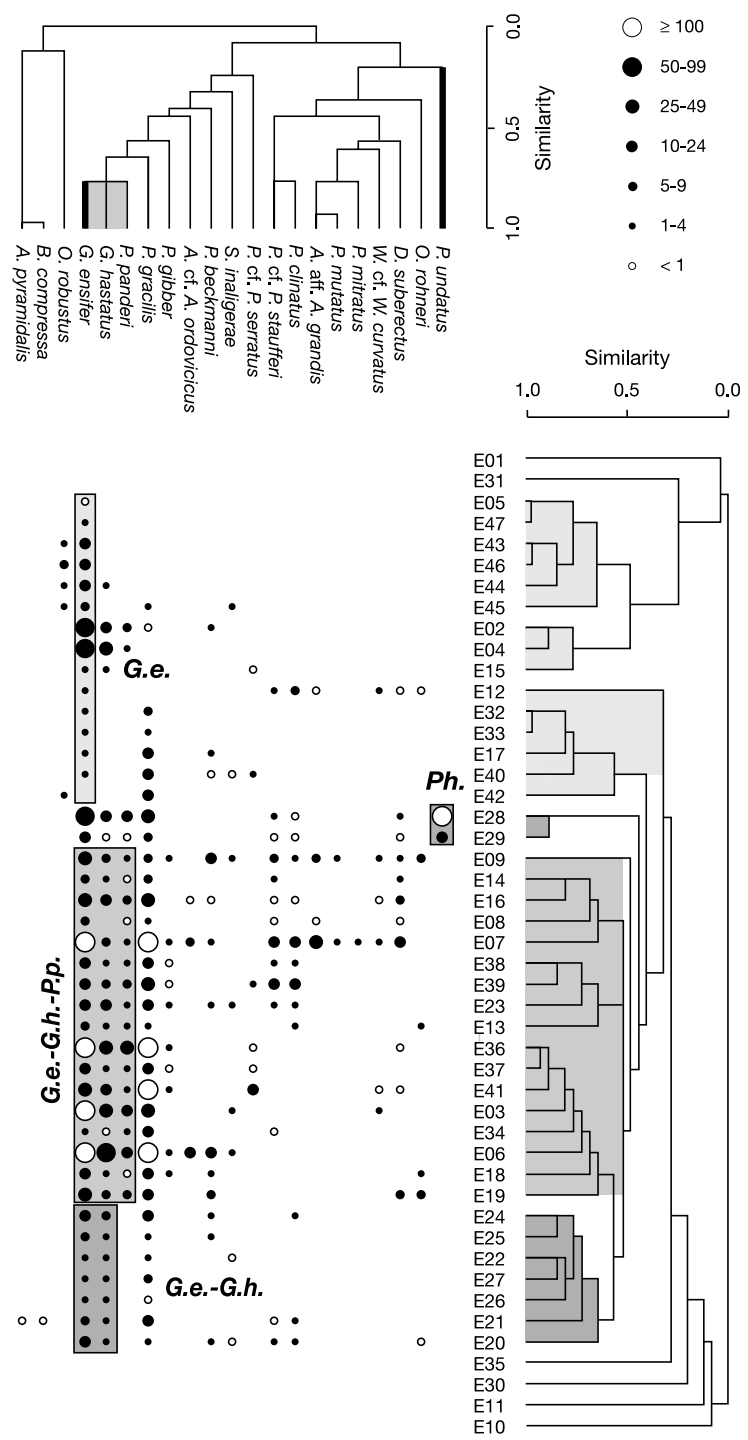

Fig. 5. Results of Q- and R-mode cluster analysis of 47 samples from Ellis Bay Formation (sample data from McCracken and Barnes, 1981). Samples are in Q-mode clustering, taxa are in $\mathrm{R}$-mode clustering order and relative abundance of taxa are expressed as a graded series of dots. Intersections of Q- and R-clusters defined four conodont communities (shaded), indicated by the abbreviations: G.e., Gamachignathus ensifer; Ph., Phragmodus undatus; G.e.-G.h.-P.p., Gamachignathus ensifer-G. hastatus-Panderodus panderi; G.e.-G.h., Gamachignathus ensifer-G. hastatus.

strong cusp curvature, which is probably part of an apparatus with $P$. liratus (Nowlan and Barnes) and $P$. cf. P. staufferi (Branson, Mehl and Branson) of McCracken and Barnes (1981); and (b) 


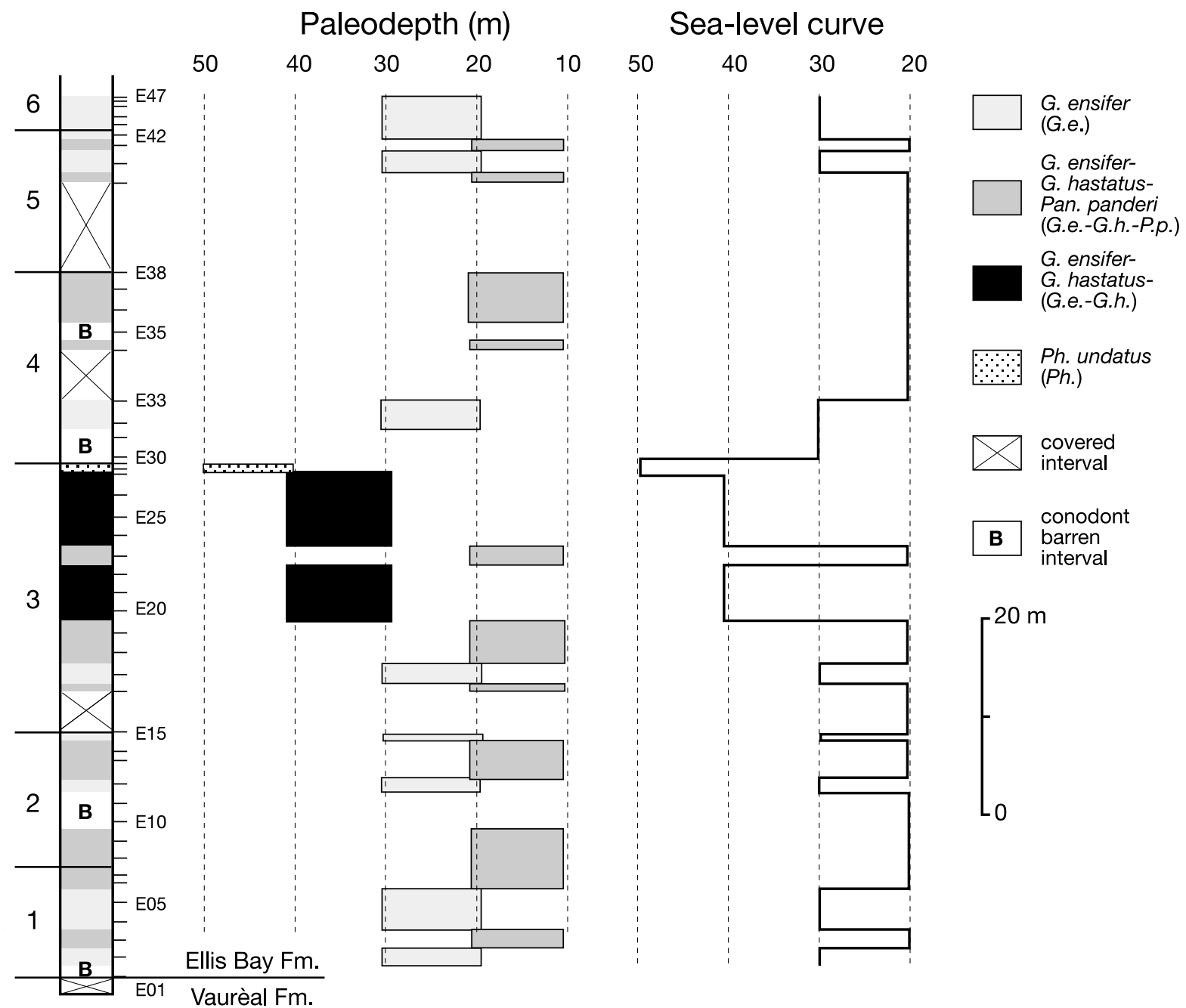

Fig. 6. Inferred paleodepth and sea level changes based on the distribution of the four conodont communities identified by cluster analysis through Ellis Bay Formation at Ellis Bay.

the abundance of G. ensifer and G. hastatus in the former is higher than the latter. There is no definitive evidence to tell which, if either, preferred deeper water. However, the G. ensifer-G. hastatus community only appears in member 3 , and the Phragmodus undatus $(P h$. $)$ community appears at the top of member 3 that represents the deepest water interval (Copper and Long, 1998). Thus, the G. ensifer-G. hastatus (G.e.-G.h.) community represents a deeper water setting than the $G$. ensifer-G. hastatus-Panderodus panderi (G.e.-G.h.$P . p$.) community.

Although four communities can be recognized through the Ellis Bay Formation (Fig. 6), most of them suggest shallower environments than those represented in the Vauréal Formation, as almost all samples from the Ellis Bay Formation produce elements of Gamachignathus which mainly appears in the shallowest conodont community, $A p$ helognathus $\mathrm{n}$. sp. A-Oulodus rohneri (Aph.-O.r.). Therefore, most of the Ellis Bay Formation communities represent the same water depth as Aphelognathus n. sp. A-Oulodus rohneri (Aph.-O.r.), or shallower. Based on the interpretation of macrofossils and sediments by Copper and Long (1998), the water depth ranged from 10 to $50 \mathrm{~m}$ for the 
Ellis Bay Formation. The presence of Phragmodus undatus in upper member 3 probably indicates a water depth greater than $50 \mathrm{~m}$. Fig. 6 summarizes the four community distributions through time and space, and the interpreted sea level curve. The cyclicity of sea level oscillations is more pronounced numerically in the Ellis Bay Formation than for any equivalent interval in thickness in the Vauréal Formation, likely in response to the glacio-eustatic changes in the Hirnantian interval.

\section{Sea level changes during the Llandovery - analysis III for the Becscie, Merrimack, Gun River, Jupiter and Chicotte formations}

The Becscie, Merrimack, Gun River, Jupiter and Chicotte formations comprise the Llandovery strata on Anticosti Island, which are 525-565 m in thickness (Petryk, 1981a). The Llandovery conodont fauna is totally different from that of Ashgillian sequence, with only a few coniform species extending from the Ordovician (McCracken and Barnes, 1981; Zhang and Barnes, 2002a).

The conodonts from the Becscie, Merrimack, and Gun River formations received preliminary study by Fåhræus and Barnes (1981) and detailed study by Zhang and Barnes (2000, 2002a), and those for the Jupiter and Chicotte formations were reported by Uyeno and Barnes (1983). The more recent multielement taxonomy has tended to reduce the species number, especially for the coniform species, than that of the Vauréal and Ellis Bay formations. The coniform species, especially those of Panderodus, occur in almost every Anticosti sample, and are of limited help in the partition of conodont communities.

The database for analysis includes 27 samples yielding 4130 specimens from the Becscie and Merrimack formations at the Rivière aux Saumons and Rivière Jupiter sections, 36 samples producing 14947 specimens from the Gun River Formation at the La Loutre coast and Rivière Jupiter sections (both from Zhang and Barnes, 2002a), and 60 samples containing 5762 specimens from the Jupiter and Chicotte formations that are mainly from sections along the south coast derived from Uyeno and Barnes (1983).
The following revisions have been made for the database of Uyeno and Barnes (1983): (a) the specimen number of coniform species was recounted, so the total specimen number is 5762 rather than 5116 as published; (b) Oulodus sp. A is assigned as Ou. panuarensis Bischoff; (c) Walliserodus sancticlairi is included in Walliserodus curvatus (Branson and Branson); (d) Oulodus sp. is included in Ou. sigmoideus Zhang and Barnes; and (e) Oulodus? fluegeli subsp. A is considered a synonym of Ou.? expansus (Armstrong).

Thus, the database of analysis comprises 123 samples and 42 species that were identified from 24839 conodont specimens using sections that span the Llandovery sequence. The analysis produced 11 conodont communities (Fig. 7), which are named as Panderodus unicostatus (P.u.), Icriodella inconstans-Ozarkodina gulletensis-Aulacognathus bullatus (I.-O.-A.), Ozarkodina strenaRexroadus nathani (Oz.s.-R.n.), Apsidognathus tuberculatus-Pterospathodus celloni-P. pennatus procerus-Carniodus carnulus-Ozarkodina polinclinata (A.-P.-P.-C.-O.), Ozarkodina aldridgei (Oz.a.), Ozarkodina oldhamensis-Rexroadus kentuckyensis (Oz.o.-R.k.), Panderodus sp. (P. sp.), Icriodella deflecta-Oulodus jeannae-Ozarkodina pirata (I.d.Ou.j.-Oz.p.), and Panderodus recurvatus (P.r.), Oulodus cf. Ou.? fluegeli-Pterospathodus siluricus-P. posteritenuis-Decoriconus fragilis $(O .-P$.P.-D.), and Ozarkodina pirata (Oz.p.) communities.

Fig. 7 shows that some communities are grouped by few species, but are represented in many samples, whereas other communities are grouped by more species, but involve fewer samples. This suggests that the former communities, such as Panderodus unicostatus (P.u.), Ozarkodina strena-Rexroadus nathani (Oz.s.-R.n.), Ozarkodina aldridgei (Oz.a.), Ozarkodina oldhamensis-Rexroadus kentuckyensis (Oz.o.-R.k.), Icriodella deflecta-Oulodus jeannae-Ozarkodina pirata (I.d.Ou.j.-Oz.p.), and Panderodus recurvatus (P.r.) were more persistent and had a wider environmental tolerance than the latter group. Some, such as Ozarkodina strena-Rexroadus nathani (Oz.s.-R.n.), Ozarkodina oldhamensis-Rexroadus kentuckyensis (Oz.o.-R.k.), and Icriodella deflecta-Oulodus jeannae-Ozarkodina pirata (I.d.- 


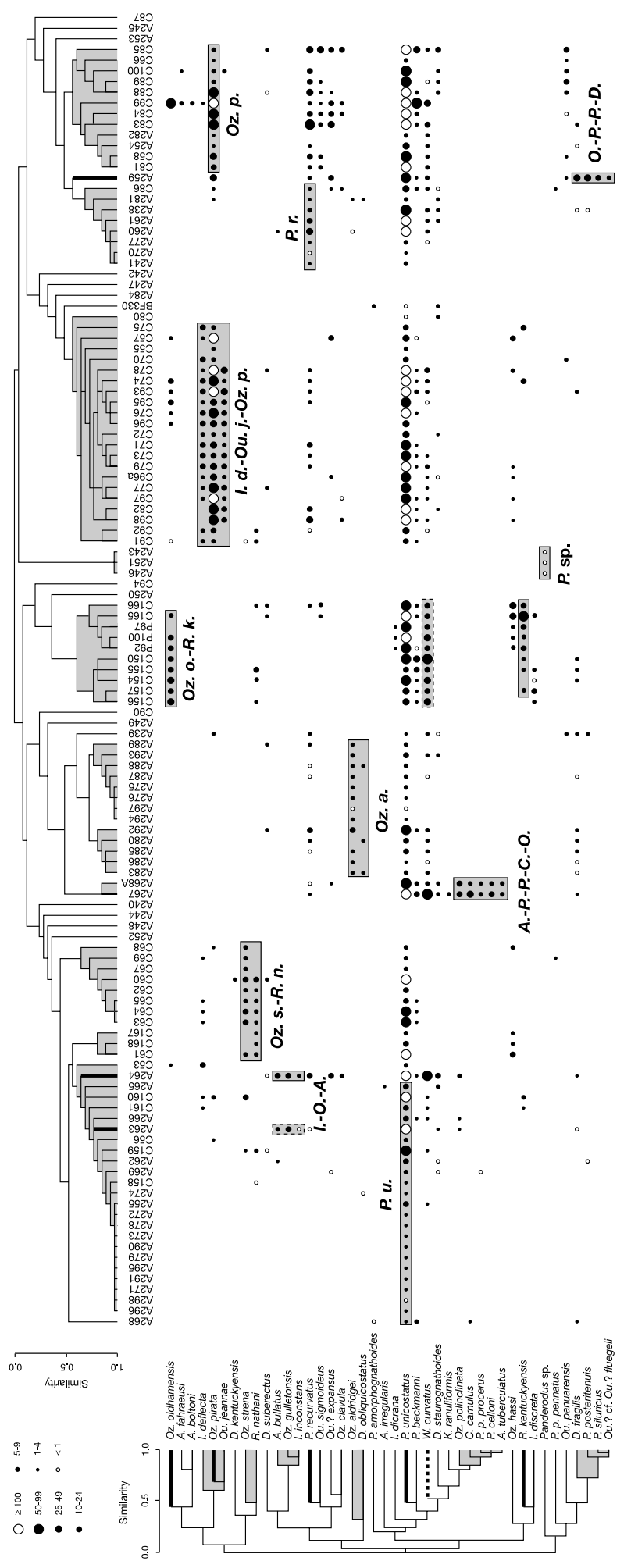


Fig. 7. Results of Q- and R-mode cluster analysis of 123 samples from Becscie, Merrimack, Gun River, Jupiter and Chicotte formations (sample data of Becscie, Merrimack, Gun River formations using C-samples from Zhang and Barnes (2002a); sample data of Jupiter and Chicotte formations using A-samples from Uyeno and Barnes, 1983). Samples are in Q-mode clustering, taxa are in R-mode clustering order, and relative abundance of taxa are expressed as a graded series of dots. Intersections of Q- and R-clusters defined 11 conodont communities (shaded), indicated by the abbreviations: P.u., Panderodus unicostatus; I.-O.-A., Icriodella inconstans-Ozarkodina gulletensis-Aulacognathus bullatus; Oz.s.-R.n., Ozarkodina strena-Rexroadus nathani; A.-P.-P.C.-O., Apsidognathus tuberculatus-Pterospathodus celloni-P. pennatus procerus-Carniodus carnulus-Ozarkodina polinclinata; Oz.a., Ozarkodina aldridgei; Oz.o.-R.k., Ozarkodina oldhamensis-Rexroadus kentuckyensis; P. sp., Panderodus sp.; I.r.-Ou.j.-Oz.p., Icriodella deflecta-Oulodus jeannae-Ozarkodina pirata; P.r., Panderodus recurvatus; O.-P.-P.-D., Oulodus? cf. Ou.? fluegeli-Pterospathodus siluricus-P. posteritenuis-Decoriconus fragilis; Oz.p., Ozarkodina pirata.

Ou.j.-Oz.p.), had a more stable development than the others (Figs. 7-10). As a species, Panderodus unicostatus has the widest distribution within the Llandovery fauna, occurring in almost every sample, but as a community it only groups 23 samples out of 123. The Panderodus unicostatus (P.u.) community may represent both the shallowest and the deepest water depths, in which other conodonts are rare or absent. Thus, the development and replacement of conodont communities in the Early Silurian appears to be more complex than those of the Late Ordovician.

\subsection{Sea level changes in the Rhuddanian}

The Becscie and Merrimack formations represent Rhuddanian strata (Fig. 8). The Becscie was divided into four informal members by Petryk (1981a), the lower two were assigned as the Fox Point and Chabot members by Copper and Long (1989) and the upper two members were incorporated into the Merrimack Formation by Copper and Long (1989).

The Ozarkodina oldhamensis-Rexroadus kentuckyensis (Oz.o.-R.k.) community exhibits stable and dominant development throughout member 1 (= Fox Point Member of Copper and Long, 1989). It is characterized by a relatively high species diversity, most of samples yielding 5-9 species. Walliserodus curvatus, Rexroadus kentuckyensis and Ozarkodina oldhamensis are three dominant species.

Idris (1984) used nine points (A-I) to divide the nearshore to offshore gradient for the Llandovery of the Oslo region, Norway. He showed that Walliserodus curvatus had a preference for deeper waters, being most common in the environment furthest offshore (Point A), represented by the deeper water Clorinda brachiopod community. In a detailed conodont paleoecological study of the Anticosti Llandovery (Zhang and Barnes, $2002 \mathrm{~b}$ ), the same community was also recognized by the same statistical method, and interpreted to have been prevalent at or below storm wave base. The abundance of $W$. curvatus in the Oz.o. - R.k. community (10-99 specimens per $\mathrm{kg}$ in all samples) stands in contrast with its low abundance in the G.e.-G.h. - P.p. community ( $>1-4$ specimens per $\mathrm{kg}$ in 5 samples out of 17), which is interpreted as a shallow water community in the Ellis Bay Formation. Thus, the occurrence of the Oz.o. - R.k. community in member 1, Becscie Formation, indicates a significant deepening after the latest Ordovician Ellis Bay Formation. In addition, the dominant lithofacies LF2 (homogenous, laminated mudstone) of member 1 also indicates relatively deep water, interpreted as being below storm wave base (Sami and Desrochers, 1992).

The Ozarkodina strena-Rexroadus nathani (Oz.s.-R.n.) community replaced the Ozarkodina oldhamensis-Rexroadus kentuckyensis (Oz.o.-R.k.) community near the boundary between members 1 and 2 (member $2=$ Chabot Member of Copper and Long, 1989). It developed through member 2 and the lower part of the Merrimack Formation (=members 3 and 4, Becscie Formation of Petryk, 1981a), being only replaced briefly by the Panderodus unicostatus and Ozarkodina pirata communities in the lower and upper parts of member 1. Except for the main components of the community, the obvious differences between the two neighboring communities are that: (a) the Ozarkodina strena-Rexroadus nathani (Oz.s.R.n.) community has a lower species diversity and 
abundance, most samples producing $2-5$ species whose specimen numbers range from 1 to 24 , mostly 1-9; and (b) all samples comprising the Ozarkodina strena-Rexroadus nathani (Oz.s.R.n.) community lack Walliserodus curvatus. These communities both indicate shallowing. $O z$. strena is a newly described species from Anticosti Island (Zhang and Barnes, 2002a) and R. nathani does not have a wide distribution like $W$. curvatus. However, Idris (1984) found that $R$. cf. $R$. nathani (referred to as Oulodus cf. Ou. nathani) ranged between Points $\mathrm{D}$ and $\mathrm{H}$ representing water depths characterized by the Stricklandia to Pentamerus brachiopod communities. Lithofacies LF4 (laminated mudstone-grainstone facies) is predominant in member 1 (Sami and Desrochers, 1992), which has abundant wave-formed structures and excellent preservation of tempestites indicating deposition above storm wave base but below fairweather wave base in approximate water depths of $30-70 \mathrm{~m}$. These features all indicate that there was a shallowing upward trend from members 1 and 2 (Fig. 11).

Besides LF4, member 2 also includes lithofacies LF5 (laminated calcisiltite-grainstone facies) that was deposited above storm wave base and probably near fairweather wave base, in approximately 10-30 m of water (Sami and Desrochers, 1992). This indicates that the whole member 2 was formed in relatively shallow water. However, this shallowing trend was not constant, but was interrupted by periodic deepening events indicated by the Ozarkodina pirata (Oz.p.) community. There is no direct evidence to establish the water depth for this community. However, the following reasons suggest a relatively deep water preference for the Oz. pirata (Oz.p.) community: (a) among 123 samples in analysis, 12 are grouped as the $O z$. pirata (Oz.p.) community; among these 123 samples, 12 contain Oulodus? expansus that is generally related to outer shelf and upper slope facies (Armstrong, 1990; Jowett and Barnes, 2000), and

Fig. 8. Distribution of the conodont communities identified by cluster analysis through the Becscie and Merrimack formations.

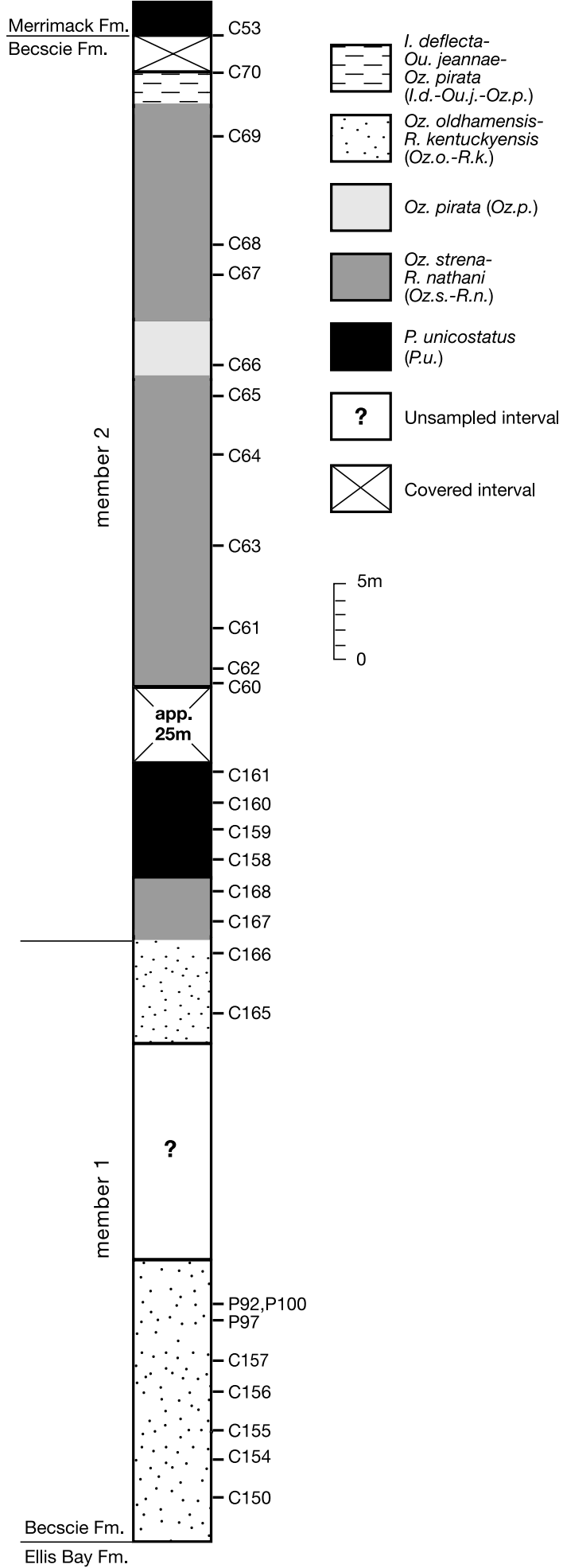


five of these 12 are assigned to the $\mathrm{Oz}$. pirata (Oz.p.) community (Fig. 7); and (b) the five samples containing Oulodus? expansus in the Oz. pirata (Oz.p.) community show the highest abundance of $\mathrm{Ou}$ ? expansus (1-24 specimens per $\mathrm{kg}$ ) among the 12 samples.

The presence of the Panderodus unicostatus (P.u.) community in the upper part of Merrimack Formation and near the boundary between the Merrimack and Gun River formations may indicate the deepest water depth in the sequence. This is supported by the presence of the LF1 lithofacies (calcareous mudstone-shale facies) in the upper Merrimack Formation, which is indicative of below-normal storm wave base (Sami and Desrochers, 1992). One sample from this interval (C57), not grouped in the P. unicostatus community, contains the first appearance of Oulodus? expansus which is generally associated elsewhere with outer shelf and upper slope facies (Armstrong, 1990; Jowett and Barnes, 2000). The Merrimack to Gun River transition may represent oscillating eustatic conditions as five samples from this interval $(\mathrm{C} 70, \mathrm{C} 53, \mathrm{C} 55, \mathrm{C} 56, \mathrm{C} 57)$ are alternately grouped in the P. unicostatus (P.u.) and the Icriodella deflecta-Oulodus jeannae-Ozarkodina pirata (I.d.-Ou.j.-Oz.p.) community, the latter likely being indicative of more shallow water (see discussion below).

\subsection{Sea level changes in the Aeronian}

The Gun River Formation and members 1-4 (lower part) of the Jupiter Formation (of Uyeno and Barnes, 1983) are of Aeronian age (Fig. 9). Members 1-4 approximate to the Goéland, East Point and Richardson members of Copper and Long (1990). As noted above, the first appearance of the Icriodella deflecta-Oulodus jeannae-Ozarkodina pirata (I.d.-Ou.j.-Oz.p.) community is in the uppermost Becscie Formation (C70), i.e. near the Rhuddanian-Aeronian boundary, and it dominates throughout the Gun River Formation. Among all the communities recognized in analysis, the Icriodella deflecta-Oulodus jeannae-Ozarkodina pirata (I.d.-Ou.j.-Oz.p.) community has the highest species diversity and abundance. Most samples contain 3-8 species, and the char-
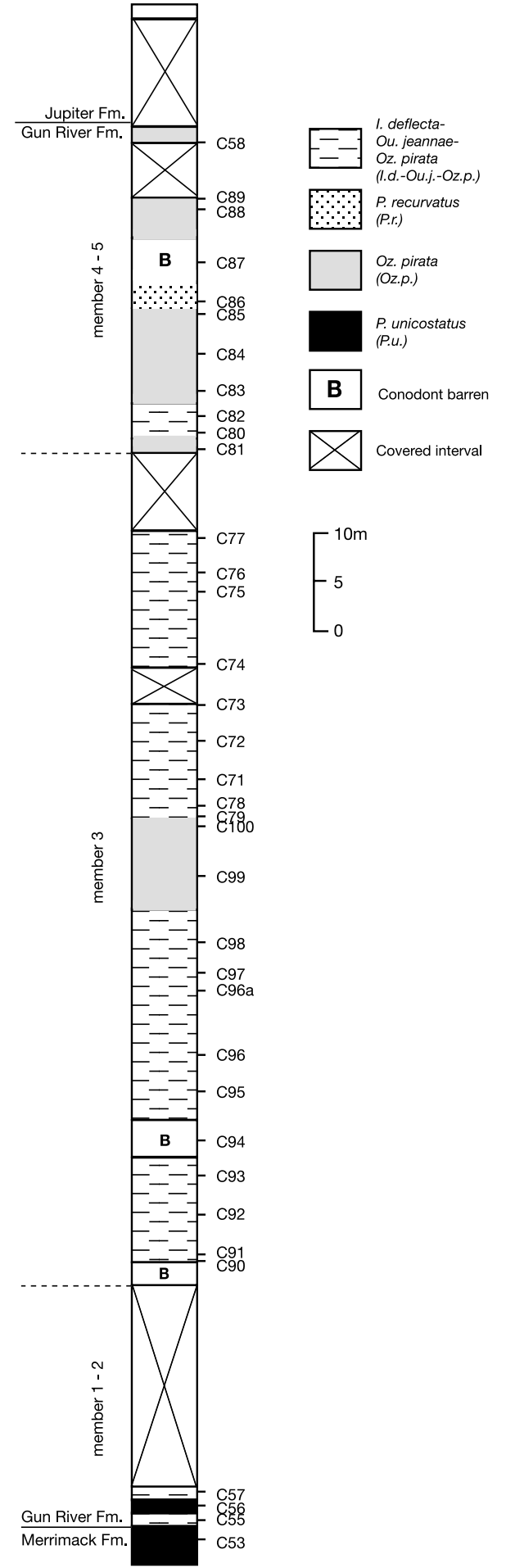

Fig. 9. Distribution of the conodont communities identified by cluster analysis through the Gun River Formation. 
acteristic species in most samples are represented by over five specimens, and Oz. pirata, in particular, by between five and over 100 specimens.

Within this community, the best indicator of water depth is Icriodella deflecta Aldridge. Idris (1984) made a detailed study of the early Llandovery conodont faunas of the Oslo Region, Norway, and found Icriodella discreta Pollock, Rexroad and Nicoll and I. deflecta to be especially common in shallow water deposits displaying channeling, ripple marks, and lenses of pebbly biosparite. In analysis, 18 of 22 samples within the Icriodella deflecta-Oulodus jeannae-Ozarkodina pirata (I.d.-Ou.j.-Oz.p.) community produce 1-24 specimens of $I$. deflecta. The second richest community with $I$. deflecta is the Ozarkodina strena-Rexroadus nathani (Oz.s.-R.n.) community in the upper part of the Becscie Formation, where four of 11 samples yield 1-4 specimens of $I$. deflecta. As interpreted above, the habitat of the Ozarkodina strena-Rexroadus nathani (Oz.s.R.n.) community was probably above storm wave base but below fairweather wave base. Based on the species abundance of I. deflecta, it can be inferred that the habitats of both the Icriodella deflecta-Oulodus jeannae-Ozarkodina pirata (I.d.-Ou.j.-Oz.p.) and Ozarkodina strena-Rexroadus nathani (Oz.s.-R.n.) communities were similar. The Gun River Formation consists primarily of rhythmic micrites and shales representing a quiet, deeper water setting (Copper and Long, 1998) with stricklandiid brachiopods in low abundance (Jin and Copper, 1999). Additionally, the Icriodella deflecta-Oulodus jeannae-Ozarkodina pirata (I.d.-Ou.j.-Oz.p.) community contains the most abundant representation of Ozarkodina pirata (a relatively deep water representative as mentioned above) among all communities, which suggests that the I.d.-Ou.j.-Oz.p. community represents slightly deeper water than the Ozarkodina strena-Rexroadus nathani (Oz.s.-R.n.) community.

The Icriodella deflecta-Oulodus jeannae-Ozarkodina pirata (I.d.-Ou.j.-Oz.p.) community was briefly replaced by the Ozarkodina pirata (Oz.p.) community in the middle part of the Gun River Formation, and then eventually replaced by it in the upper part of the formation. This indicates that sea levels during Gun River time were moderately high, but increased briefly in the middle and again at the end.

A study of the brachiopods (Jin and Copper, 1999) shows a development of the Pentamerus community near the top of Gun River Formation and at the base of the Jupiter Formation, indicating a shallowing event near the formational boundary. Unfortunately, no conodont collections came from the base of Jupiter Formation.

The lowest sample (A259) from the Jupiter Formation contains a special conodont community, i.e. the Oulodus? cf. Ou.? fluegeli-Pterospathodus siluricus-Pterospathodus posteritenuis-Decoriconus fragilis $(O .-P .-P .-D$.) community. It is the only sample among 123 in analysis yielding $O u$.? cf. Ou.? fluegeli and having the highest abundance of D. fragilis (10 specimens per $\mathrm{kg}$ ). These two species were interpreted as being specialists of offshore environments (Aldridge and Jeppsson, 1984). Hence, the $O .-P .-P .-D$. community in the middle part of member 1 in the Jupiter Formation, represents a relatively high sea level (Fig. 11).

Two other communities, Panderodus recurvatus (P.r.) and Ozarkodina aldridgei (Oz.a.), first appeared alternately in the upper part of member 1, Jupiter Formation (Fig. 10). Member 2 of the Jupiter Formation is not exposed on the south coast. Member 3 yields only conodonts of the Panderodus sp. (P.r.) community, represented by just three tiny specimens of $P$. sp. found in three samples, respectively. Member 3 comprises shale, locally sandy, which may represent a local clastic influx from the Canadian Shield to the north and probably a brief period of shallowing (Uyeno and Barnes, 1983). This interpretation is supported by the discovery of land-derived microfossils in the member (Duffield, 1985). This member probably represents the lowest sea level on Anticosti during the Llandovery (Fig. 11).

\subsection{Sea level changes in the Telychian}

Telychian strata are exposed on Anticosti Island as member 4 ( $\approx$ Cybèle, Ferrum and Pavillon members of Copper and Long, 1990) of the 


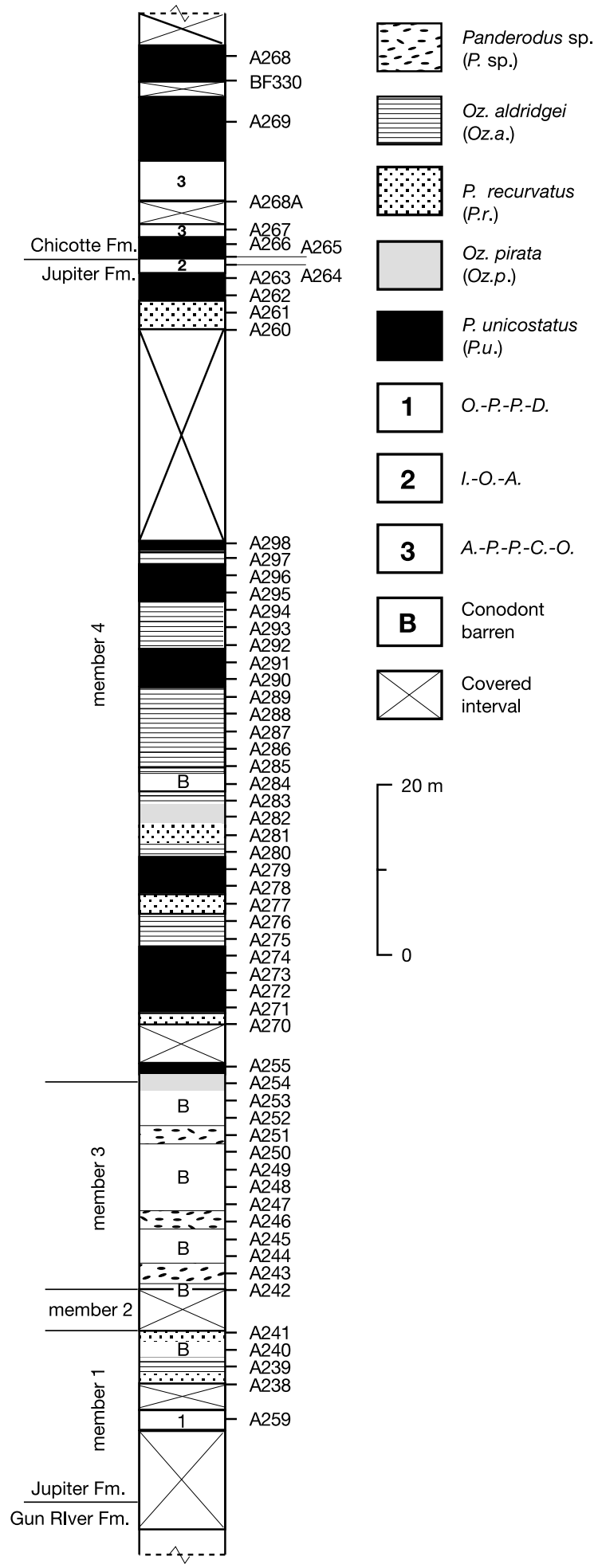

Jupiter Formation and the lower part of Chicotte Formation (Fig. 10); there is no clear evidence of uppermost Telychian or of Wenlock age strata. The pattern of conodont communities through member 4 of the Jupiter Formation is quite different from those in the underlying strata. Four conodont communities, Panderodus unicostatus (P.u.), Panderodus recurvatus (P.r.), Ozarkodina aldridgei (Oz.a.) and Ozarkodina pirata (Oz.p.), replaced each other in a repetitive pattern (Figs. 10 and 11).

The Panderodus recurvatus (P.r.) community first appeared in the upper part of the Gun River Formation. This community has its closest relationship with the Ozarkodina pirata community; both are linked by $P$. recurvatus, which suggests that the water depth for the $P$. recurvatus community was similar to that of the Ozarkodina pirata (Oz.p.) community. In analysis III, both Icriodella deflecta-Oulodus jeannae-Ozarkodina pirata (I.d.-Ou.j.-Oz.p.) and Ozarkodina pirata (Oz.p.) communities contain abundant Ozarkodina pirata. The Ozarkodina pirata (Oz.p.) community yields more abundant Oulodus? expansus than any other communities, and consequently the water depth of the Ozarkodina pirata (Oz.p.) community was deeper than that of the Icriodella deflecta-Oulodus jeannae-Ozarkodina pirata (I.d.Ou.j.-Oz.p.) community as discussed earlier. Thus, the water depth of the $P$. recurvatus community that generally lacks Ozarkodina pirata should be deeper than that of the Ozarkodina pirata (Oz.p.) community.

The Ozarkodina aldridgei (Oz.a.) community originates in the Jupiter Formation and $\mathrm{Oz}$. aldridgei is a characteristic species. The distinctive $\mathrm{Pa}$ element of $\mathrm{Oz}$. aldridgei is similar to that of $O z$. oldhamensis that is most common in the Ozar-

Fig. 10. Distribution of the conodont communities identified by cluster analysis through the Jupiter and Chicotte formations (O.-P. - P. $-D .=$ Oulodus? cf. Ou. ? fluegeli-Pterospathodus siluricus $-P$. posteritenuis-Decoriconus fragilis community; I. - O. - A. $=$ Icriodella inconstans - Ozarkodina gulletensis - Aula cognathus bullatus community; A. - P. - P-.C. - O. $=$ Apsidognathus tuberculatus-Pterospathodus celloni-P. pennatus procerusCarniodus carnulus-Ozarkodina polinclinata community). 
Paleodepth (m)

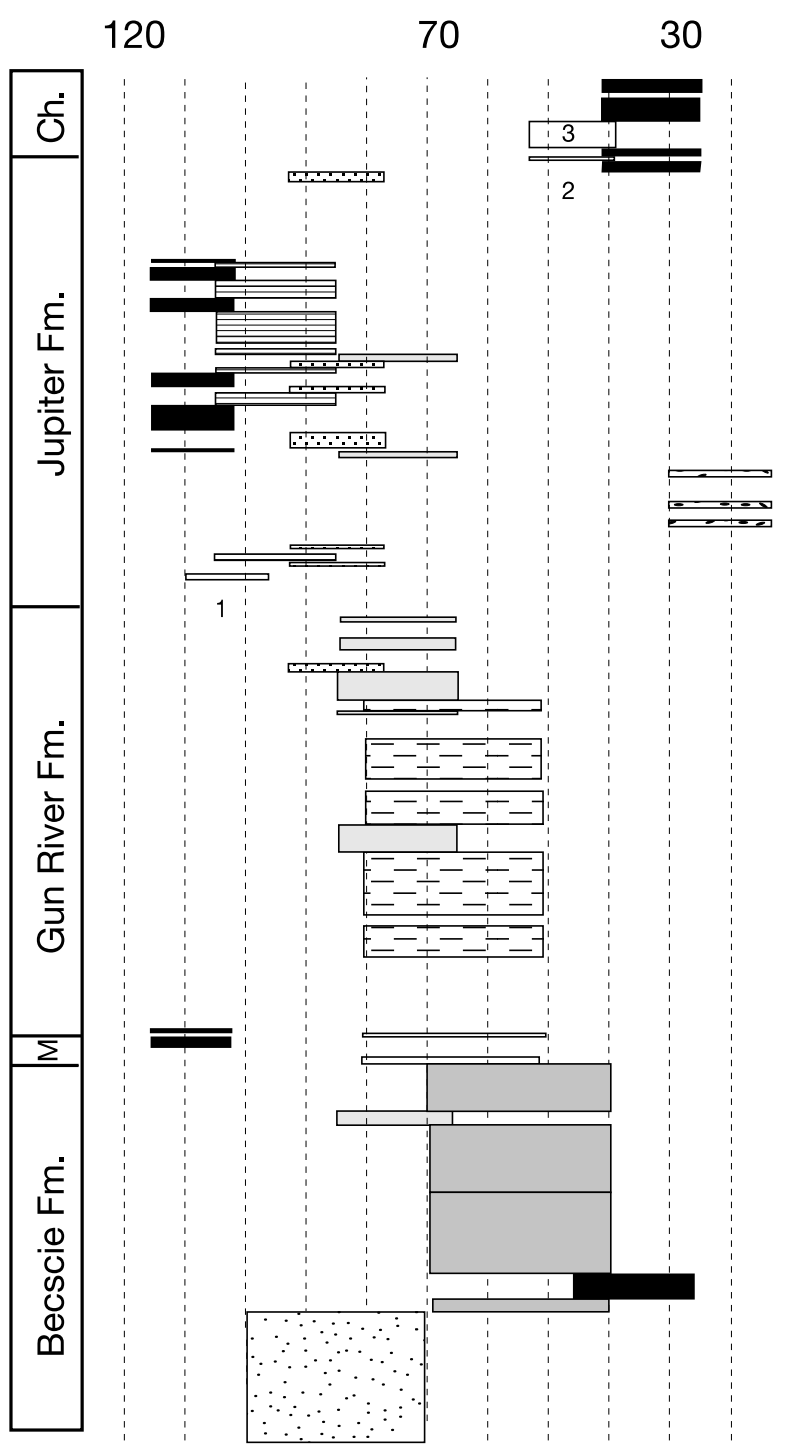

Sea-level curve 120 70
Panderodus sp.

Ozarkodina aldridgei

Pandrodus recurvatus

Icriodella deflecta-

Oulodus jeannea-

Ozarkodina pirata
Ozarkodina strenaRexroadus nathani

Panderodus unicostatus

Ozarkodina oldhamensis Rexroadus kentuckyensis

Ozarkodina pirata

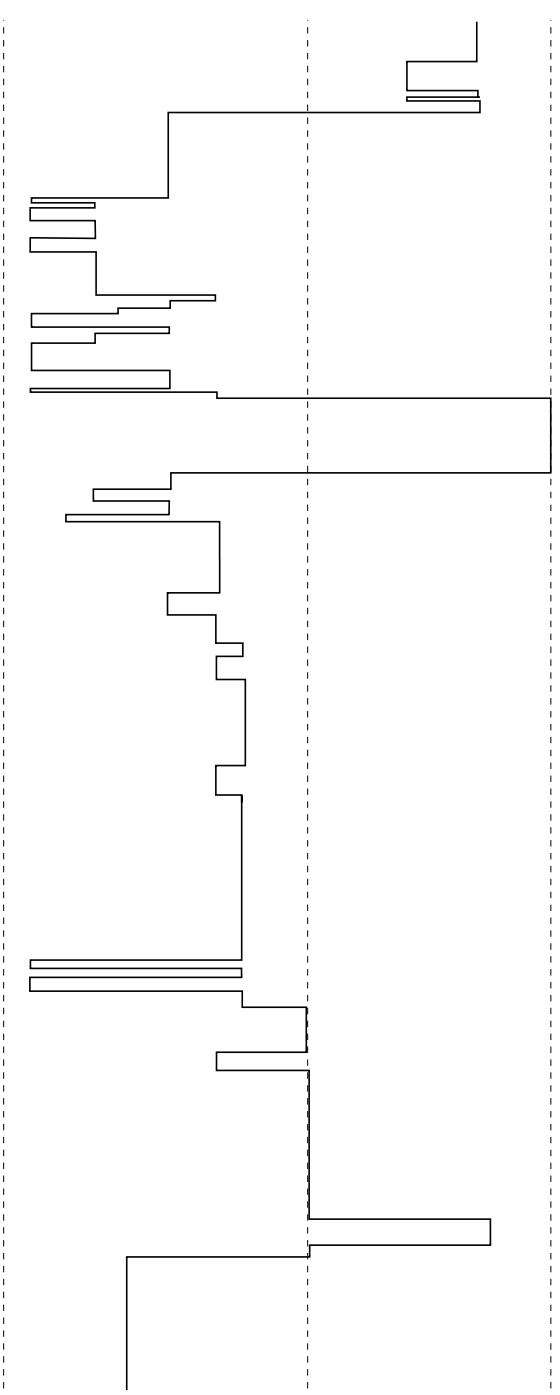

1 O.-P.-P.-D.

2 I.-O.-A.

3 A.-P.-P.-C.-O. 
kodina oldhamensis-Rexroadus kentuckyensis (Oz.o.-R.k.) community in the early Rhuddanian. A cladistic analysis suggests that $O z$. oldhamensis and $O z$. aldridgei shared a common ancestry, and the latter is interpreted as being transformed through the pseudoextinction of the former by the acquisition of an additional derived character state of basal cavity (located at about mid-length of the blade) (Zhang and Barnes, in preparation). Hence, Oz. aldridgei and Oz. oldhamensis probably preferred a similar water depth below storm wave base. The other characteristic species are Decoriconus fragilis and Dapsilodus obliquicostatus (Branson and Mehl). Both of these are rare through the whole Llandovery on Anticosti Island; among 123 samples in the analysis, eight of 19 yielding $D$. fragilis and three of five producing $D$. obliquicostatus are grouped under the $O z$. aldridgei (Oz.a.) community. This indicates that the water depth of $D$. obliquicostatus and $D$. fragilis is also equivalent to that of the $O z$. aldridgei (Oz.a.) community. A strikingly high proportion of $D$. obliquicostatus was documented by Aldridge and Mabillard (1981) in the most offshore localities across the Early Silurian shelf of the Wales/ Welsh Borderland area. Decoriconus fragilis is also common in more offshore areas of this shelf (Aldridge and Jeppsson, 1984). A similar dominance has been also noted in other areas, for instance, North Greenland (Armstrong, 1990) and Arctic Canada (Jowett and Barnes, 2000), where the outer shelf and upper slope communities contain $D$. obliquicostatus and D. fragilis. Thus, the Ozarkodina aldridgei (Oz.a.) community represents a deep water environment, perhaps deeper than that of the Ozarkodina oldhamensis-Rexroadus kentuckyensis (Oz.o.-R.k.) community in the early Rhuddanian.

The common characteristic of the four communities in member 4 of Jupiter Formation is the low species diversity and abundance. Most samples from this interval grouped under the Pan- derodus unicostatus (P.u.) community only produce the eponymous species, with low abundance (one to four specimens per $\mathrm{kg}$ ). This suggests deeper water than that of the Ozarkodina aldridgei (Oz.a.) community, with the latter being likely the deepest community of the Llandovery Anticosti conodonts except for the $P$. unicostatus community. Most of the 14 samples grouped under the Ozarkodina aldridgei (Oz.a.) community contain two to four species, only one (A239) produced eight species, and most of these are only represented by less than one to nine specimens per $\mathrm{kg}$. Similarly, most samples from this interval grouped under the $P$. recurvatus (P.r.) community also show a lower species diversity and abundance than other samples from the Gun River Formation. The P. unicostatus (P.u.), Oz. aldridgei (Oz.a.), P. recurvatus (P.r.) and Oz. pirata (Oz.p.) communities through member 4 of the Jupiter Formation indicate four different but alternating water depths from deep to shallow, but still deeper than any other communities from the underlying strata. This pattern suggests more oscillating sea levels than seen in the underlying strata.

Near the Jupiter-Chicotte boundary, two shortlived communities can be recognized. They are Icriodella inconstans-Ozarkodina gulletensis-Aulacognathus bullatus (I.-O.-A.) and Apsidognathus tuberculatus-Pterospathodus celloni-P. pennatus procerus-Carniodus carnulus-Ozarkodina polinclinata (A.-P.-P.-C.-O.). Each is represented by only two adjacent samples. Among the former, Oz. gulletensis and I. inconstans have been interpreted as nearshore inhabitants during the preamorphognathoides and post-amorphognathoides intervals, respectively (Aldridge and Mabillard, 1981). However, Au. bullatus may not have a strong environmental preference, and occurs widely in small numbers almost everywhere as recorded by Armstrong (1990). In that study, the relative abundance peaks of $C$. carnulus dur-

Fig. 11. Inferred paleodepth and sea level changes based on the distribution of the 11 conodont communities identified by cluster analysis through Becscie, Merrimack, Gun River, Jupiter and Chicotte formations $(\mathrm{M}=$ Merrimack Fm.; Ch $=$ Chicotte Fm.; O.$P .-P .-D .=$ Oulodus? cf. Ou. ? fluegeli-Pterospathodus siluricus $-P$. posteritenuis - Decoriconus fragilis community; I. $-O .-A .=I c r i o d e l-$ la inconstans-Ozarkodina gulletensis-Aulacognathus bullatus community; A.-P.-P.-C.-O. = Apsidognathus tuberculatus - Pterospathodus celloni-P. pennatus procerus-Carniodus carnulus-Ozarkodina polinclinata community). 
ing the amorphognathoides interval and $P$. celloni during the pre-amorphognathoides interval are related to a more offshore environment (Aldridge and Mabillard, 1981) than their presence in the Icriodella inconstans-Ozarkodina gulletensis-Aulacognathus bullatus (I.-O.-A.) community.

The crinoidal grainstone of the uppermost Jupiter and lower Chicotte formations is possibly an initial indication of a regional shallowing phase (Uyeno and Barnes, 1983) corresponding to shallow shoal bank environment.

\section{Discussion}

\subsection{Ashgillian-Llandovery sea level curve for} Anticosti Island

Fig. 12 summarizes the Anticosti conodont community distribution through time and space. Fig. 13 illustrates the sea level curve derived from Ordovician-Silurian conodont communities from the Ashgillian-Llandovery sequence on Anticosti Island. It also compares with the smoothed sea

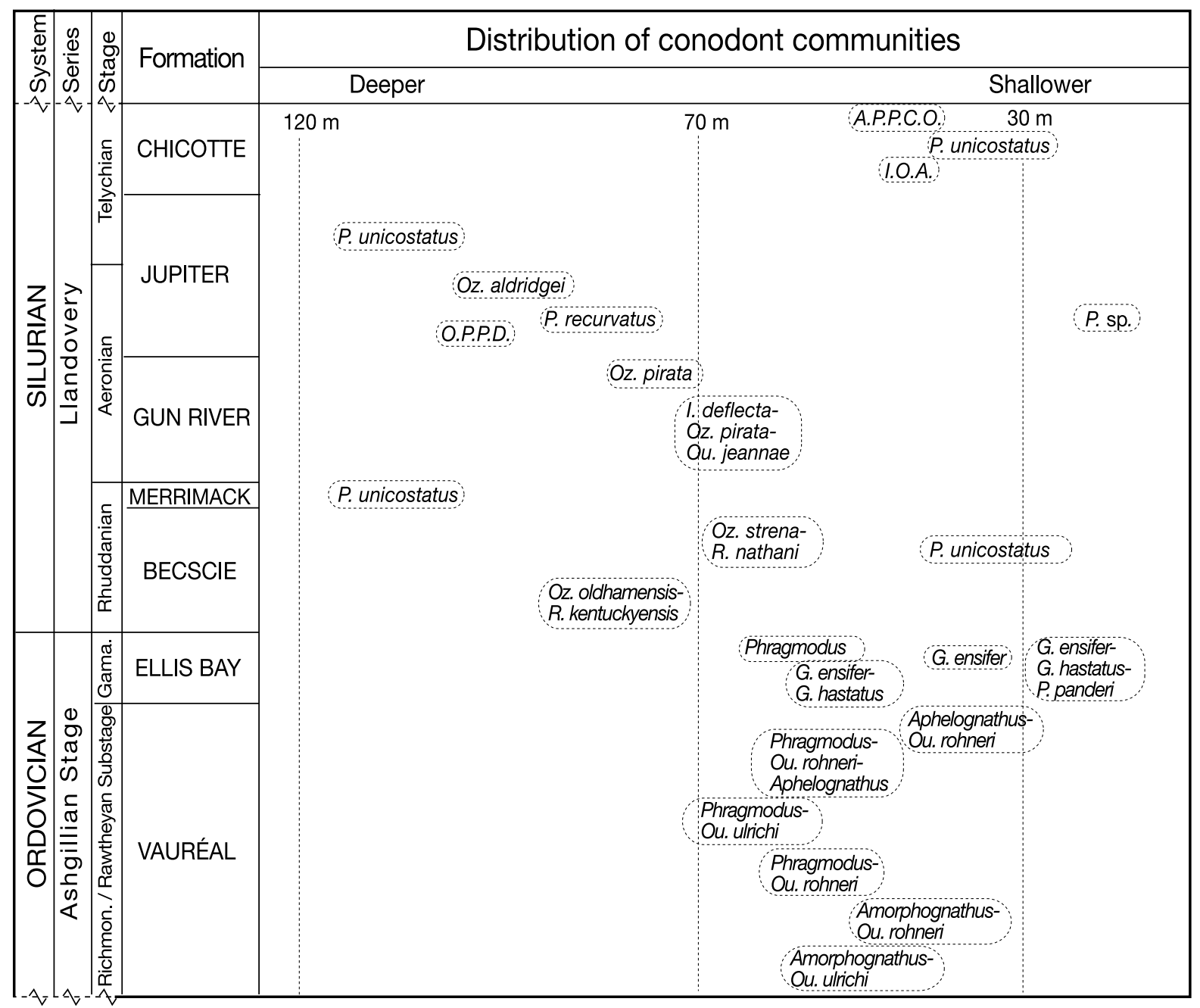

Fig. 12. Summary of conodont community distribution through space and time during the Late Ordovician and Early Silurian on Anticosti Island (O.P.P.D. $=$ Oulodus? cf. Ou. ? fluegeli-Pterospathodus siluricus - P. posteritenuis-Decoriconus fragilis community; I.O.A. = Icriodella inconstans-Ozarkodina gulletensis-Aulacognathus bullatus community; A.P.P.C.O. = Apsidognathus tuberculatus-Pterospathodus celloni-P. pennatus procerus-Carniodus carnulus-Ozarkodina polinclinata community). 


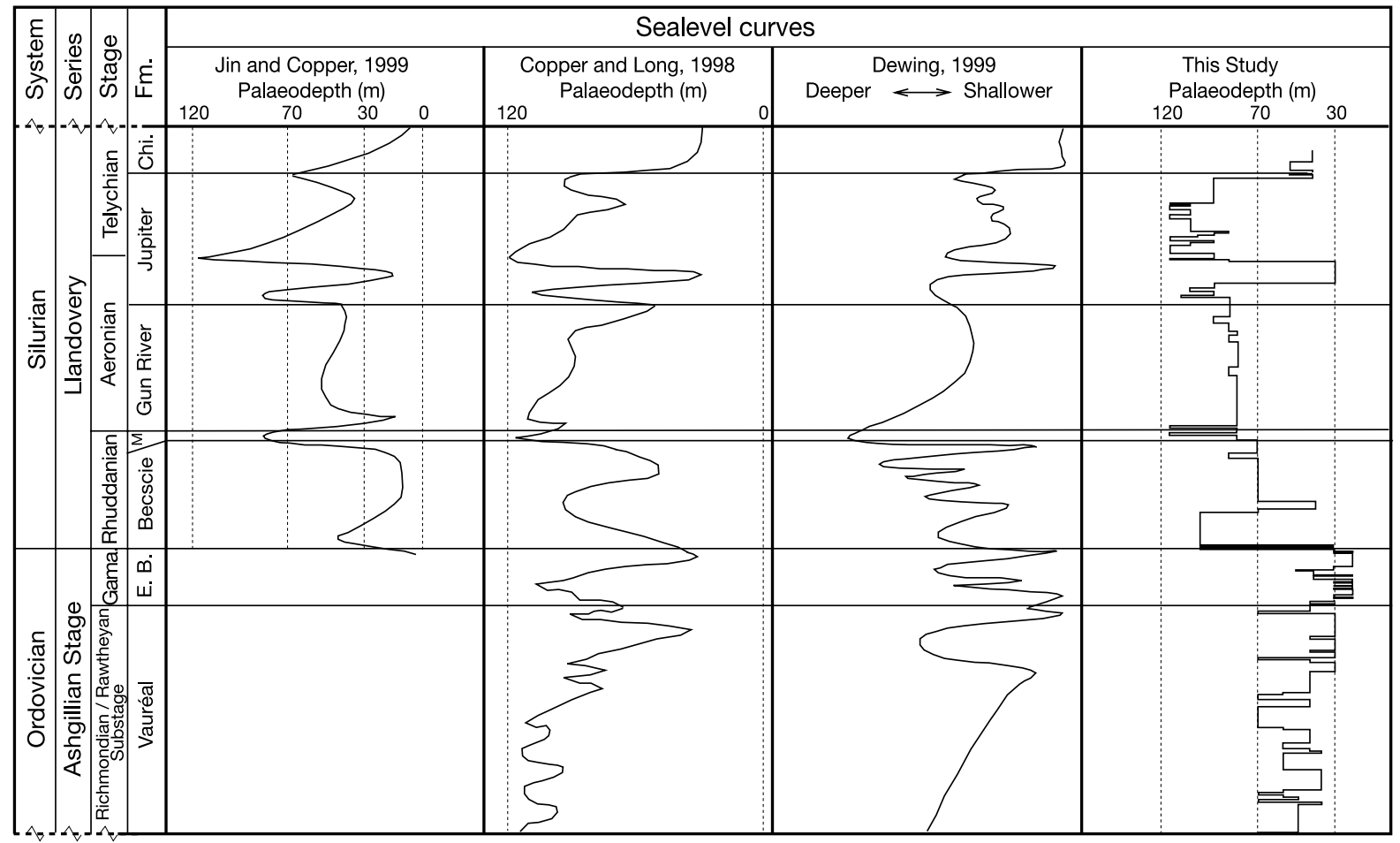

Fig. 13. Comparison of the sea level curve and paleodepths inferred by the distribution of conodont communities with those curves inferred by macrofossils and sediments through the Upper Ordovician and Lower Silurian sequence on Anticosti Island $(\mathrm{M}=$ Merrimack Fm.; $\mathrm{Ch}=$ Chicotte Fm. $)$.

level curves proposed previously by Copper and Long (1998), Jin and Copper (1999), and Dewing (1999) based on sediments and brachiopod and reef communities. These different authors used slightly different formational thicknesses, and Fig. 13 adjusts the thickness of each formation used by Copper and Long (1998), Jin and Copper (1999), and Dewing (1999) to match the same scale.

There is some contradiction between sea level curves and the paleodepths for the Vauréal Formation established by Copper and Long (1998). Fig. 2 (modified from Copper and Long, 1998) shows the paleodepths of the Vauréal as occurring between 20 and $70 \mathrm{~m}$, with two shallow to deep cycles based on sedimentary structures. However, the sea level curve based on the paleocommunities is deeper, almost as deep as that of Merrimack Formation (maximum $120 \mathrm{~m}$ ), with sea level gradually shallowing from lower to upper Vauréal with six secondary shallow to deep cycles (Fig. 13). Dewing's (Fig. 13) sea level curve exhibits a gradual shallowing without any significant deepening or shallowing events in the lower and middle part of Vauréal. However, it shows a sharp deepening in the upper part of the formation, contrary to that of Copper and Long (1998). The sea level curve proposed herein is similar to that of Copper and Long (1998), but shows more variations of deepening and shallowing.

The sea level curve for the Ellis Bay Formation of Copper and Long (1998), Dewing (1999) and this study are similar, although this study shows a more oscillating pattern in the lower part of the formation than the former two.

Dewing (1999) recognized three small regressive cycles within an overall transgression through the Becscie and Merrimack formations, based largely on the curve of Sami and Desrochers (1992). Both Jin and Copper (1999) and Copper and Long 
(1998) recognized one major regression in this interval. The curve derived from the conodont community pattern for this interval supports that of Jin and Copper (1999) and Copper and Long (1998) with only minor differences, but not that of Dewing (1999).

The conodont communities in the few samples from the Merrimack Formation are similar to those of the upper Becscie Formation, which does not reflect the deepening phase suggested by brachiopod community evidence. However, the rapid replacement of conodont communities does suggest a major transgression in the upper part of Merrimack Formation and near the Merrimack-Gun River boundary (Rhuddanian-Aeronian boundary), slightly later than that recognized by Jin and Copper (1999), Copper and Long (1998) and Dewing (1999).

In the Gun River interval, conodont communities remained relatively constant, only punctuated by other communities representing deeper water in the upper part of the formation. This is a similar pattern to that suggested for the brachiopod communities.

In the lower Jupiter Formation interval, the sea levels constructed by different authors show a similar pattern with two major transgressions and one regression. However, in the middle and late Jupiter interval, this study reveals a much more oscillating sea level pattern than do the others. This study does not recognize a transgression near the boundary between the Jupiter and Chicotte formations, contrary to the other studies. A marked regression occurred in the lower Chicotte interval, associated with the widespread crinoidal shoal facies, recognized by all authors.

\subsection{Comparison to the Ashgillian-Llandovery global sea level curve}

Based on sequence stratigraphic correlations of key Ordovician sections in North America and Europe, Ross and Ross (1992) concluded that Upper Ordovician sequences were deposited during a series of transgressions-regressions that were associated with generally high eustatic sea levels (Mohawkian and Cincinnatian). The changes of Richmondian conodont communities on Anticosti
Island reflect these eustatic sea level changes. According to Ross and Ross (1992), a global sea level drop occurred in the Gamachian with only one brief transgression. This may be reflected in the brief appearance of the Phragmodus undatus community in the middle Ellis Bay Formation.

The sudden changes in conodont communities near the Ordovician-Silurian boundary and the stable development of new Llandovery conodont communities on Anticosti Island do not support the conclusion of Ross and Ross (1992) that, after the Gamachian, sea level gradually rose through a series of transgressions and regressions at the beginning of the Silurian. The pattern of conodont communities suggests a rapid rise of sea level in the beginning of the Silurian (Fig. 14).

Highest Llandovery sea level is reached near the Rhuddanian-Aeronian boundary (between the Merrimack and Gun River formations), as reflected in the appearance of the Panderodus unicostatus community along with Oulodus? expansus, a deep water specialist species. This highstand probably correlates with the upper Coronograptus cyphus Zone and lower Demirastrites triangulatus Zone, which approximates to the highstand recognized by Johnson (1996) and Johnson et al. (1991) that they correlated with the C. cyphus Zone, but does not support a lowstand recognized by Ross and Ross (1996) (Fig. 14).

Loydell (1998) considered that sea level reached a maximum in the early Aeronian Demirastrites triangulatus to early Diplograptus magnus zones. However, recent stratigraphic and isotopic data suggests that a minor glaciation occurred in South America at or close to the D. triangulatus Zone (Grahn and Caputo, 1992; Grahn, 1996; Caputo, 1998; Veizer et al., 1999) which supports the likelihood of an early Aeronian regression. The Atavograptus atavus Zone on Anticosti Island equates approximately with the $D$. triangulatus Zone (Zhang and Barnes, 2002a) and in this interval conodont communities indicate a stable development in relatively shallow water (Fig. 14).

The development and replacement of conodont communities indicate two highstands in the latest Aeronian. The first one is earlier than the graptolite Stimulograptus sedgwickii Zone, and the second one coincides with the first appearance of $S$. 


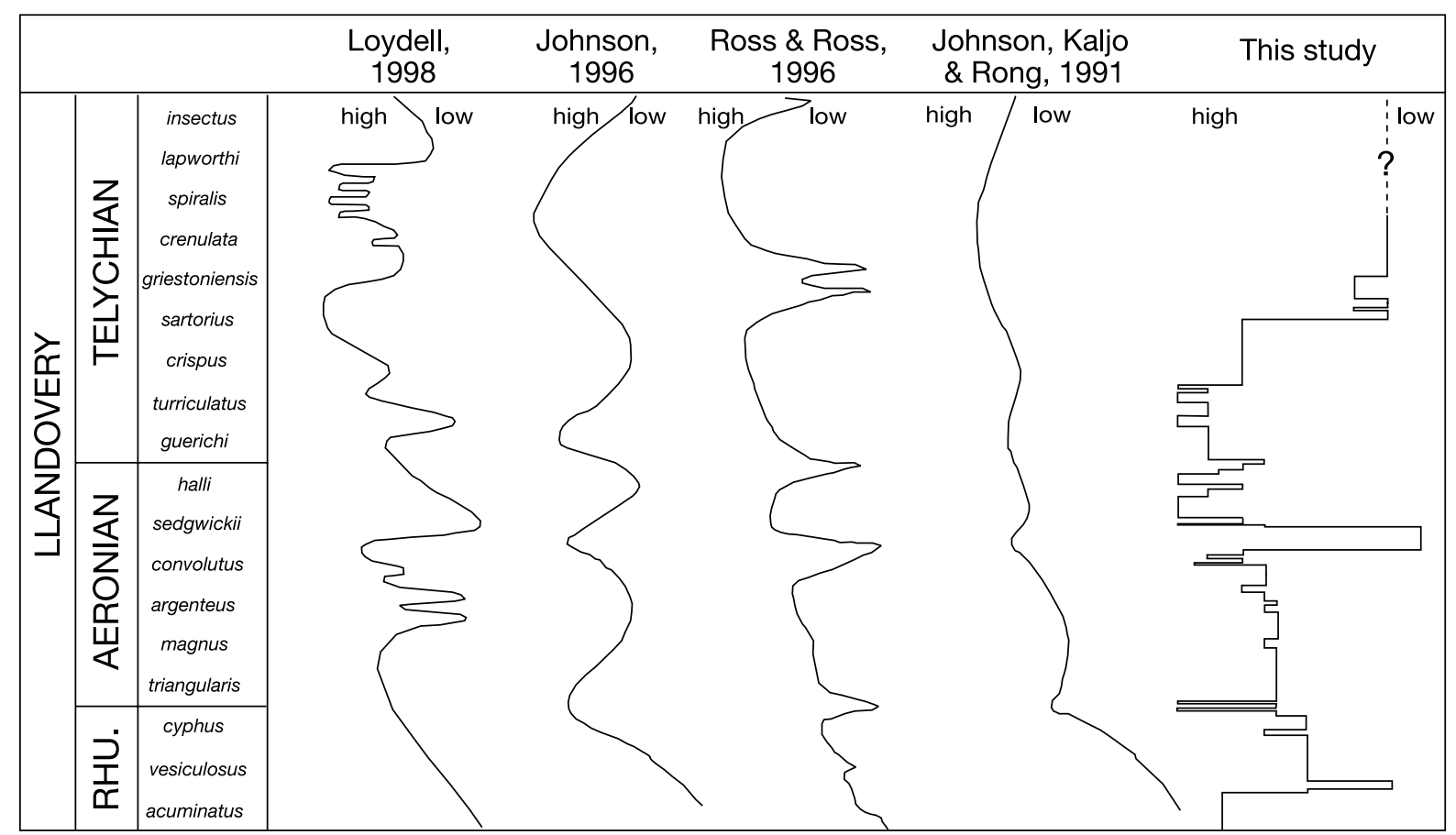

Fig. 14. New sea level curve inferred by the distribution of Anticosti Llandovery conodont communities (right), compared with other proposed global Llandovery sea level curves (modified from Loydell, 1998). Zones are drawn arbitrarily as of equal duration (as in Loydell, 1998), but this creates a slightly different duration of chronostratigraphic units from that used in Figs. 11 and 13 .

sedgwickii. Between these two highstands, there is a pronounced lowstand represented by the Panderodus sp. community, which was also recognized by Ross and Ross (1996); a lowstand is correlated with the S. sedgwickii Zone by Loydell (1998) (Fig. 14). The latest Aeronian glaciation recorded in South America is also correlated with this graptolite zone by Veizer et al. (1999).

No zonal graptolites have been found in the Chicotte Formation, so precise correlation is difficult. On the basis of conodont and brachiopod biostratigraphy (Barnes, 1989), the Chicotte ranges at least as high as Telychian $\mathrm{C}_{5}$ and the graptolite Monoclimacis crenulata Zone. The lowstand recognized by the conodont communities in the Chicotte Formation is contrary to the highstand related to $M$. crenulata Zone and conodont Pterospathodus amorphognathoides Zone recognized by Ross and Ross (1996) and Johnson (1996).

\section{Conclusions}

Anticosti Island, Québec, provides the most complete and fossiliferous section in the world for the Ashgillian-Llandovery (Upper Ordovician-Lower Silurian) interval. The predominantly limestone succession accumulated in the gently subsiding Anticosti Basin and preserves a valuable record of changing sea levels. Earlier workers have derived sea level curves based on aspects of stratigraphy and sedimentology, and or brachiopod and reef communities. Virtually the entire sequence has been sampled in detail for conodonts, and underpinned by taxonomy. The resulting database of over 77600 conodonts secured from 272 samples has allowed, using paleoecological statistical analysis, the recognition of a complex pattern of conodont communities. These are correlated to paleobathymetry as inferred from the known details of the stratigraphy, sedimentology 
and macrofossil communities. From the spatial and temporal distribution of conodont communities derived from this detailed sampling base, a refined sea level curve has been established for the Anticosti sequence. It is compared to sea level curves developed by other workers that were based on sedimentary structures, and brachiopod and reef communities with which it is in general agreement, but shows more subtle changes and is better constrained stratigraphically. The Anticosti sea level curve is also compared to the global eustasy curves developed recently for this interval by other workers.

Some distinct patterns have emerged from the analysis and the interpretations, namely:

- Each conodont community maintained its particular environmental preferences and interpreted water depths through this interval.

- Sea level changes resulted in the rapid displacement of communities.

- During periods of relatively stable sea level, the communities likewise maintained a stable development and typically had a relatively high species diversity and abundance during these brief periods of stasis.

- During periods of oscillating sea level, different communities were replaced rapidly and typically had a relatively low species diversity and abundance.

- The Panderodus unicostatus community tolerated both the extreme deep and shallow water environments represented in the sequence that other conodont communities avoided, likely due to the eurytopic nature of this species.

The main periods of regression in the sequence can be correlated relatively well to the intervals of eustatic lowstand generated by the Gondwana glaciation, for both the main glacial events in the Hirnantian/Gamachian and in the three brief intervals in the Llandovery that are also indicated by the recently documented oxygen isotope excursions.

\section{Acknowledgements}

C.R.B. gratefully acknowledges financial support for conodont research from the Natural
Sciences and Engineering Research Council of Canada. G.S. Nowlan, A.D. McCracken, S.L. Duffield and S. Gardiner provided field assistant support in the field for the development of the database. Advice on stratigraphic sections was generously provided by T.E. Bolton, M.J. Copeland, and A.A. Petryk. Permission and support to undertake geological field work on Anticosti Island was given by Ministère des Richesses Naturelles, Québec and the Ministère du Tourisme, de la Chasse et de la Pêche, Québec. Support for this paleoecological analysis and eustasy study was provided by a Pan-LITHOPROBE grant.

\section{References}

Aldridge, R.J., 1976. Comparison of macrofossil communities and conodont distribution in the British Silurian. In: Barnes, C.R. (Ed.), Conodont paleoecology. Geological Association of Canada Special Paper 15, pp. 92-104.

Aldridge, R.J., Jeppsson, L., 1984. Ecological specialists among Silurian conodonts. Paleontology 32, 141-149.

Aldridge, R.J., Mabillard, J.E., 1981. Local variations in the distribution of Silurian conodonts: an example from the amorphognathoides interval of the Welsh Basin. In: Neale, J.W., Brasier, M.D. (Eds.), Microfossils from Recent and Fossil Shelf seas. Ellis Horwood, Chichester, pp. 10-17.

Armstrong, H.A., 1990. Conodonts from the Upper Ordovician-Lower Silurian carbonate platform of north Greenland. Grønlands Geologiske Undersøgelse Bull. 159, GGU, Copenhagen, pp. 1-151.

Azmy, K., Veizer, J., Bassett, M.G., Copper, P., 1998. Oxygen and carbon isotopic composition of Silurian brachiopods: implications for coeval seawater and glaciations. Geol. Soc. Am. Bull. 110, 1499-1512.

Barnes, C.R. (Ed.), 1976. Conodont Paleoecology. Geological Association of Canada Special Paper 15, pp. 1-324.

Barnes, C.R., 1986. The faunal extinction event near the Ordovician-Silurian boundary: a climatically induced crisis. In: Walliser, O.H. (Ed.), Global Bioevents. Lecture Notes in Earth Sci. 8. Springer, Berlin, pp. 121-126.

Barnes, C.R., 1988. Stratigraphy and paleontology of the Ordovician-Silurian boundary interval, Anticosti Island, Québec. In: Cocks, L.R.M., Rickards, R.B. (Eds.), A Global Analysis of the Ordovician-Silurian Boundary. Bull. British Museum (Natural History) Geology 43, pp. 195-219.

Barnes, C.R., 1989. Lower Silurian chronostratigraphy of Anticosti Island, Québec. In: Holland, C.H., Bassett, M.G. (Eds.), A Global Standard for the Silurian System. National Museum of Wales, Geol. Ser. 9, pp. 101-108.

Barnes, C.R., 1992. The uppermost series of the Ordovician System. In: Webby, B.D., Laurie, J.R. (Eds.), Global Per- 
spectives on Ordovician Geology. AA Balkema, Rotterdam, pp. 185-192.

Barnes, C.R., Bergström, S.M., 1988. Conodont biostratigraphy of the upper Ordovician and lowermost Silurian. In: Cocks, L.R.M., Rickards, R.B. (Eds.), A Global Analysis of the Ordovician-Silurian Boundary. Bull. British Museum (Natural History) Geology 43, pp. 325-343.

Barnes, C.R., Fåhræus, L.E., 1975. Provinces, communities, and proposed nektobenthonic habit of Ordovician conodontophorids. Lethaia 8, 133-149.

Barnes, C.R., Petryk, A.A., Bolton, T.E., 1981. Anticosti Island, Québec. In: Lespérance, P.J. (Ed.), IUGS Subcommission on Silurian Stratigraphy (Ordovician-Silurian Boundary Working Group) Field Meeting. Anticosti-Gaspé, Québec 1981, Vol. 1: Guidebook. pp. 1-24.

Barrick, J.E., 1983. Wenlockian (Silurian) conodont biostratigraphy, biofacies, and carbonate lithofacies, Wayne Formation, Central Tennessee. J. Paleontol. 57, 208-239.

Bergström, S.M., 1990. Relations between conodont provincialism and the changing paleogeography during the early Paleozoic. In: McKerrow, W.S., Scotese, C.R. (Eds.), Paleozoic Paleogeography and Biogeography. Memoir Geological Soceity of London 12, pp. 105-121.

Berner, R.A., 1994. GEOCARB II: A revised model of atmospheric $\mathrm{CO}_{2}$ over Phanerozoic time. Am. J. Sci. 294, 56-91.

Bolton, T.E., 1972. Geological map and notes on the Ordovician and Silurian litho- and biostratigraphy, Anticosti Island, Québec. Geological Survey of Canada Paper 71-19, p. $1-45$.

Brenchley, P.J., Marshall, J.D., Carden, G.A.F., Robertson, D.B.R., Long, D.G.F., Meidla, T., Hints, L., Anderson, T.F., 1994. Bathymetric and isotope evidence for a shortlived Late Ordovician glaciation in a greenhouse period. Geology 22, 295-298.

Caputo, M.V., 1998. Ordovician-Silurian glaciations and global sea-level changes. In: Landing, E. Johnson, M. (Eds.), Silurian Cycles: Linkages of dynamic stratigraphy with atmospheric, oceanic, and tectonic changes. New York State Museum Bull. 491, pp. 15-25.

Clark, D.L. (Ed.), 1984. Conodont Biofacies and Provincialism. Geological Society of America Special Paper 196, p. 1340.

Copper, P., Long, D.G.F., 1989. Stratigraphic revisions for a key Ordovician/Silurian boundary section, Anticosti Island, Canada. Newsl. Stratigr. 21, 59-73.

Copper, P., Long, D.G.F., 1990. Stratigraphic revision of the Jupiter Formation, Anticosti Island, Canada: a major reference section above the Ordovician-Silurian boundary. Newsl. Stratigr. 23, 11-36.

Copper, P., Long, D.G.F., 1998. Sedimentology and paleontology of the Late Ordovician through Early Silurian shallow water carbonates and reefs of the Anticosti Island, Québec. Sedimentology and paleontology of the Early Ordovician through Early Silurian shallow water carbonates of the Mingan Islands National Park and Anticosti Island, Québec. Field Trip B8 Guidebook, Geol. Assoc. Can. (GAC), Min. Assoc. Can. (MAC), Assoc. des géologues et géophysicien du Québec (APGGQ), Int. Assoc. Hydrogeologists (IAH), Can. Geophys. Union (CGU) Joint Annual Meeting, 1998, Québec, pp. 55-94.

Dewing, K., 1999. Late Ordovician and Early Silurian strophomenid brachiopods of Anticosti Island, Québec, Canada. Paleontogr. Can. 17, pp. 1-143.

Duffield, S.L., 1985. Land-derived microfossils from the Jupiter Formation (Upper Llandovery), Anticosti Island, Québec. J. Paleontol. 59, 1005-1010.

Fåhræus, L.E., Barnes, C.R., 1981. Conodonts from the Becscie and Gun River formations (Lower Silurian) of Anticosti island, Québec. In: Lespérance, P.J. (Ed.), Subcommission on Silurian stratigraphy, Ordovician-Silurian boundary Working Group. Field Meeting, Anticosti-Gaspé, Québec 1981, Vol.2: Stratigraphy and Paleontology, pp. 165-172.

Fortey, R.A., 1984. Global earlier Ordovician transgressions and regressions and their biological implications. In: Bruton, D.L. (Ed.), Aspects of the Ordovician System. Paleontological Contributions from the University of Oslo, pp. 37-50.

Grahn, Y., 1996. Ordovician and Silurian glaciations in Brazil. Abstract. In: 1 Simposio Sul Americano do Siluro-Devoniano-Estratigrafia e Paleontologia. Anais di 1 Simpósio Sul Americano do Siluro-Devoniano: Estratigrafia e Paleontologia. Ponta Grossa, Pr. Gráfica Planeta, pp. 299-308.

Grahn, Y., Caputo, M.V., 1992. Early Silurian glaciations in Brazil. Paleogeogr. Paleoclimatol. Paleoecol. 99, 9-15.

Idris, M.B., 1984. Local variations in the distribution of Silurian conodonts of the Distomodus kentuckyensis Zone of the Oslo Region, Norway. Nor. Geol. Tidsskr. 64, 181191.

Jin, J., Copper, P., 1999. The deep-water brachiopod Dicoelosia King, 1850, from the Early Silurian tropical carbonate shelf of Anticosti Island, eastern Canada. J. Paleontol. 73, 1042-1055.

Johnson, M.E., 1996. Stable cratonic sequences and a standard for Silurian eustasy. In: Witzke, B.J., Ludvigson, G.A., Day, J. (Eds.), Paleozoic Sequence Stratigraphy: Views from the North American Craton. Geological Society of America Special Paper 306, pp. 203-211.

Johnson, M.E., Cocks, L.R.M., Copper, P., 1981. Late Ordovician-Early Silurian fluctuations in sea level from eastern Anticosti Island, Québec. Lethaia 14, 73-82.

Johnson, M.E., Kaljo, D.L., Rong, J.-Y., 1991. Silurian eustasy. In: Bassett, M.G., Lane, P.D., Edwards, D. (Eds.), The Murchison Symposium: Proceedings of an International Conference on the Silurian System. Special Papers in Paleontology 44, pp. 145-163.

Jowett, D.M.S., Barnes, C.R., 2000. Lower Silurian conodont biostratigraphy: integrating traditional paleontological data. GeoCanada 2000 Geoscience Summit, Abstract on conference CD.

Landing, E., Johnson, M. (Eds.), 1998. Silurian Cycles: Linkages of dynamic stratigraphy with atmospheric, oceanic, and tectonic changes. New York State Museum Bull. 491, p. 1327.

Leatham, W.B., 1997. Paleoecologic, paleobiogeographic, and evolutionary controls on conodont biostratigraphy across 
the Ordovician-Silurian systemic boundary. Abstracts with Programs, Geological Society of America 29, p. 103.

Le Fèvre, J., Barnes, C.R., Tixier, M., 1976. Paleoecology of Late Ordovician and Early Silurian conodontophorids, Hudson Bay Basin. In: Barnes, C.R. (Ed.), Conodont paleoecology. Geological Association of Canada Special Paper 15 , pp. 69-89.

Lespérence, P.J. (Ed.), 1981. IUGS Subcommission on Silurian Stratigraphy (Ordovician-Silurian Boundary Working Group) Field Meeting, Anticosti-Gaspé, Québec 1981, Vol. 2: Stratigraphy and Paleontology, p. 1-321.

Long, D.G.F., Copper, P., 1987. Stratigraphy of the Upper Ordovician Vauréal and Ellis Bay formations, eastern Anticosti Island, Québec. Can. J. Earth Sci. 24, 1807-1820.

Loydell, D.K., 1998. Early Silurian sea-level changes. Geol. Mag. 135, 447-471.

McCracken, A.D., Barnes, C.R., 1981. Conodont biostratigraphy and paleoecology of the Ellis Bay Formation, Anticosti Island, Québec, with special reference to Late Ordovician Early Silurian chronostratigraphy and the systemic boundary. Geol. Surv. Can. Bull. 329, 51-134.

McCracken, A.D., Nowlan, G.S., Barnes, C.R., 1980. Gamachignathus, a new multielement conodont genus from the latest Ordovician, Anticosti Island, Québec. Current Research, Part C, Geological Survey of Canada Paper 80-C1, pp. 103-112.

Nowlan, G.S., Barnes, C.R., 1981. Late Ordovician conodonts from the Vauréal Formation, Anticosti Island, Québec. Geol. Surv. Can. Bull. 329, 1-49.

Petryk, A.A., 1981a. Stratigraphy, sedimentology and paleogeography of the Upper Ordovician - Lower Silurian of Anticosti Island, Québec. In: Lespérance, P.J. (Ed.), Subcommission on Silurian stratigraphy, Ordovician-Silurian boundary Working Group. Field Meeting, Anticosti-Gaspé, Québec 1981, Vol. 2: Stratigraphy and paleontology, pp. 1139.

Petryk, A.A., 1981b. Upper Ordovician glaciation: effects of eustatic fluctuations on the Anticosti platform succession, Québec. In: Lespérance, P.J. (Ed.), Subcommission on Silurian stratigraphy, Ordovician-Silurian boundary Working Group. Field Meeting, Anticosti-Gaspé, Québec 1981, Vol. 2: Stratigraphy and paleontology, pp. 81-85.

Pohler, S.L., Barnes, C.R., 1990. Conceptual models in conodont paleoecology. Courier Forsch.inst. Senckenberg 118, 409-440.

Poussart, P.F., Weaver, A.J., Barnes, C.R., 1999. Late Ordovician glaciation under high atmospheric $\mathrm{CO}_{2}$ : A coupled model analysis. Paleoceanography 14, 542-558.
Roliff, W.A., 1968. Oil and gas exploration - Anticosti Island, Québec. Proc. Geol. Assoc. Can. 19, 31-36.

Ross, C.A., Ross, R.P., 1996. Silurian sea-level fluctuations. In: Witzke, B.J., Ludvigson, G.A., Day, J. (Eds.), Paleozoic Sequence Stratigraphy: Views from the North American Craton. Geological Society of America Special Paper 306, pp. 187-192.

Ross, J.R., Ross, C.A., 1992. Ordovician sea-level fluctuations. In: Webby, B.D., Laurie, J.R. (Eds.), Global Perspectives on Ordovician Geology. Proc. 6th Int. Symp. on the Ordovician System, pp. 327-335.

Sami, T., Desrochers, A., 1992. Episodic sedimentation on an early Silurian, storm-dominated carbonate ramp, Becscie and Merrimack formations, Anticosti Island, Canada. Sedimentology 39, 355-381.

Seddon, G., Sweet, W.C., 1971. An ecologic model for conodonts. J. Paleontol. 45, 869-880.

SPSS, 1994. SPSS version 6.1 for the Macintosh. SPSS Inc., Chicago, IL.

Sweet, W.C., Bergström, S.M., 1974. Provincialism exhibited by Ordovician conodont faunas. Soc. Econ. Paleontol. Mineral. Spec. Publ. 21, 189-202.

Sweet, W.C., Bergström, S.M., 1984. Conodont provinces and biofacies of the Late Ordovician. Geological Society of America Special Paper 96, pp. 69-87.

Uyeno, T.T., Barnes, C.R., 1983. Conodonts of the Jupiter and Chicotte formations (Lower Silurian), Anticosti Island Québec. Geol. Surv. Can. Bull. 355, 1-49.

Veizer, J., Ala, D., Azmy, K., Bruckschen, P., Buhl, D., Bruhn, F., Carden, G.A.F., Diener, A., Ebneth, S., Godderis, Y., Jasper, T., Korte, C., Pawellek, F., Podlaha, O.G., Strauss, H., 1999. ${ }^{87} \mathrm{Sr} /{ }^{86} \mathrm{Sr}, \delta^{13} \mathrm{C}$ and $\delta^{18} \mathrm{C}$ evolution of Phanerozoic seawater. Chem. Geol. 161, 59-88.

Westrop, S.R., Cuggy, W.B., 1999. Comparative paleoecology of Cambrian trilobite extinctions. J. Paleontol. 73, 337354.

Zhang, S., Barnes, C.R., 2000. Anticostiodus, a new multielement conodont genus from the Lower Silurian, Anticosti Island, Québec. J. Paleontol. 74, 662-669.

Zhang, S., Barnes, C.R., 2002a. A new Llandovery (Early Silurian) conodont biozonation and conodonts from the Becscie, Merrimack and Gun River formations, Anticosti Island, Québec. Paleont. Soc. Mem. 57 (J. Paleont. 76(2), suppl, 1-46.

Zhang, S., Barnes, C.R., 2002b. Paleoecology of Llandovery conodonts, Anticosti Island, Québec. Palaeogeogr. Palaeoclimatol. Palaeoecol., S0031-0182(01)00422-9. 